\title{
The Role of Different Raw Materials in Lithic Technology and Settlement Patterns During the Middle Stone Age of Southern Africa
}

\author{
Manuel Will
}

Accepted: 6 June 2021 / Published online: 10 July 2021

(C) The Author(s) 2021

\begin{abstract}
The study of raw materials is an essential step in lithic analysis, regardless of the age, provenance, and technology of the assemblages. As in many other contexts of the Paleolithic, researchers of the Middle Stone Age (MSA) in southern Africa have often focused their attention on fine-grained, nonlocal rock types, such as silcrete. Here, I spotlight raw materials considered to be of lower suitability for knapping and frequently acquired from local sources. Due to their coarse-grained nature, artifacts from rock types such as calcrete, sandstone, and quartzite might show attributes that are different from finer-grained materials. Some of these knapped stones even constitute the substrate of the sites they are from, at times resulting in their neglect or not being recognized as anthropogenic artifacts. Knapped vein quartz features sharp and durable edges, but its complicated fracture mechanics hamper comparative analysis and provide methodological challenges. In this study, raw materials from different transport distances and with
\end{abstract}

Archaeological time period: Middle Stone Age/Stone Age

Country and region discussed: South Africa, KwaZuluNatal/Western Cape

M. Will $(\bowtie)$

Department of Early Prehistory and Quaternary Ecology, University of Tübingen, Schloss Hohentübingen,

72070 Tübingen, Germany

e-mail: manuel.will@uni-tuebingen.de different presumed qualities are compared in terms of their roles in MSA lithic technology and settlement patterns. In the first step, the article focuses on the open-air special-purpose camp of Hoedjiespunt 1 (HDP1, Western Cape) and the rockshelter residential site of Sibudu (KwaZulu-Natal), especially on assemblages dated between $\sim 130-100$ and $\sim 58$ ka. Subsequently, I review relevant materials for the southern African MSA. At HDP1 and Sibudu, local raw materials of lower knapping suitability assume several roles, from the "staple" material for all manufacturing stages to special-purpose and "add-on" functions. In the broader southern African region, MSA knappers also used these rock types in a flexible manner with gradual differences but also similarities to their use of finer-grained raw material. These differences depend on a complex interaction of raw material availability, differential site use, and the position of the localities in the settlement system.

Resúmé L'étude des matières premières est une étape essentielle de l' analyse lithique, quels que soient l'âge, la provenance et la technologie des assemblages concernés. Comme dans de nombreux autres contextes du Paléolithique, les chercheurs du Middle Stone Age (MSA) en Afrique australe ont souvent concentré leur attention sur des types de roches non locales à grain fin, comme le silcrete. Ici, je mets en lumière les matières premières considérées comme moins aptes au taillage qui étaient fréquemment acquises auprès de sources locales. En raison de leur nature à 
gros grains, les artefacts provenant de types de roches comme le calcaire, le grès et le quartzite peuvent montrer différentes expressions des attributs des matériaux à grains plus fins. Certaines de ces pierres taillées constituent même le substrat des sites d'où elles proviennent, ce qui entraîne parfois leur négligence ou leur non-reconnaissance comme des artefacts anthropiques. Le quartz veiné taillé présente des arêtes vives et durables, mais sa mécanique de rupture compliquée entrave les analyses comparatives et pose des défis méthodologiques. Dans cette étude, les matières premières de différentes distances de transport et de qualité présumée sont comparées en termes de leur rôle pour la technologie lithique MSA et les modèles de mobilité. D'abord, l'étude porte sur le campement à ciel ouvert de Hoedjiespunt 1 (Cap-Occidental) et le site résidentiel abri sous roche de Sibudu (KwaZuluNatal), sur des assemblages datés entre 130-100 ka et $\sim 58 \mathrm{ka}$. Par la suite, je passe en revue les documents pertinents pour la MSA d'Afrique australe. Chez HDP1 et Sibudu, les matières premières locales moins aptes à la taille jouent plusieurs rôles, du matériau « de base» pour toutes les étapes de fabrication aux fonctions spéciales et « complémentaires». Au niveau de l'Afrique australe, les tailleurs de MSA ont utilisé ces types de roches de manière flexible avec des différences et similitudes avec l'utilisation de matières premières plus fines. Ces différences dépendent d'une interaction complexe entre la disponibilité des matières premières, l'utilisation différentielle des sites et la position des localités dans le système de mobilité.

\section{Introduction}

Lithic raw material constitutes the physical source for stone tool technology. Therefore, the study of raw materials is an essential step in lithic analyses, regardless of the provenance, age, and technology of specific assemblages. Analyses of the natural distribution, accessibility, knapping quality, and package size of different rock types, as well as their consequent procurement, transport, use, and discard, provide manifold insights into past behaviors (e.g., Andrefsky, 1994; Bamforth, 1986; Binford, 1979, 1980; FéblotAugustins, 1997; Gould, 1980; Kelly, 1983; Kuhn, 1992, 1994; Nelson, 1991; Riel-Salvatore \& Barton, 2004; Terradillos-Bernal \& Rodríguez-Álvarez, 2017; Tomasso \& Porraz, 2016).
In many spatial and temporal contexts of the Paleolithic, archaeologists have focused their attention on the role of fine-grained, "high-quality" rock types. In the European Paleolithic, this phenomenon is called "flint thinking" (Knutsson, 1998, 2014). This term refers to an underappreciation of nonflint materials, both in archaeological assemblages and from a methodological point of view. For over a century, scholars in Paleolithic Europe based their technological and typological classifications predominantly on flint assemblages and then imposed them on raw materials with different flaking properties. Knutsson $(1998,2014)$ explicates these problems for quartz assemblages, which have been frequently interpreted as "archaic" or "amorphous" due to their different appearances. Researchers in the Middle Stone Age (MSA) of southern Africa, a period dating between 300 and $30 \mathrm{ka}$ and associated with the early evolution of Homo sapiens, have not been exempt from this bias for fine-grained rocks.

In southern Africa, numerous diverse raw materials appear in MSA assemblages, but none corresponds to the classic "flint" category of Europe. Yet, a similar focus on the role of "fine-grained" and often non-local raw materials (silcrete, in particular) can be observed in the past decades, mirroring some of the observations from Europe. The procurement and the use of silcrete have been associated with specific techno-complexes, increased levels of mobility and ranging patterns, technological innovations such as heat-treatment, formalized technologies such as backing, bifacial and pressure flaking, and even symbolic behavior (Ambrose \& Lorenz, 1990; Brown et al., 2012; Henshilwood et al., 2001; Lombard et al., 2012; Mackay et al., 2014; McCall, 2007; Mourre et al., 2010; Schmidt et al., 2013; Singer \& Wymer, 1982; Will \& Mackay, 2017; Wurz, 1999). Other, mostly local, raw materials such as quartzite are frequent in many assemblages (e.g., Elands Bay Cave, Klasies River, Pinnacle Point 13B, and Die Kelders; Grine, et al., 1991; Schmid, et al., 2016; Singer \& Wymer, 1982; Thackeray, 2000; Thompson et al., 2010; Volman, 1981; Wurz, 2002) but have rarely been at the center of scientific debates (but see Schmid et al., 2016).

Recently, there have been an increased number of experimental and archaeological studies of quartz in the MSA and LSA of southern Africa, particularly in relation to bipolar, microlithic, and bifacial technology (e.g., de la Peña \& Wadley, 2014; de la 
Peña et al., 2013; Pargeter, 2016; Rots et al., 2017). Yet, only a few quartz-dominated assemblages in the southern African MSA exist and have been studied with modern analytical methods. The sites and assemblages that have received such attention include Hoedjiespunt 1 (Will et al., 2013), Varsche Rivier 003 (Steele et al., 2016), Layer 8 at Die Kelders (Thackeray, 2000), the Late MSA J-I at Elands Bay Cave (Porraz et al., 2016), and PBA/PBB at Klipdrift (Douze et al., 2018). In addition to quartzite and quartz, the raw materials used during the MSA in southern Africa include sandstone and calcrete which feature flaking properties that deviate from classic conchoidal fracturing as in flint, the latter breaking similar to glass models (e.g., Dogandžić et al., 2020). In this article, these raw materials are collectively referred to as having lower-knapping suitability instead of the more value-laden term "low-quality" that has been used to denote them. Whether such raw materials were indeed perceived differently by past knappers and how they differ from other rock types will be part of this analysis.

Here, I examine these often less-studied and presumably difficult to knap raw materials occurring at many sites, including calcrete, sandstone, and quartzite. Quartz is added to this list as it features special fracture mechanics, often causes challenges for archaeologists studying it, and might require different analytical approaches (see, e.g., Driscoll, 2011a). In most cases, these rock types were acquired from local sources, and some even derive from the underlying geology that formed the sheltered parts of sites such as HDP1 (calcrete rockshelter; Will et al., 2013), Sibudu (sandstone rockshelter; Wadley \& Jacobs, 2006), Umbeli Belli (quartzite rockshelter; Bader et al., 2018), and Elands Bay Cave (quartzite cave; Schmid et al., 2016). This "ultra-local" acquisition of raw materials (see Rios-Garaizar, 2016) can be separated analytically from other local primary or secondary sources that are several kilometers away. Based on principal energetic assumptions from behavioral ecology and the technological organization of huntergatherers (Andrefsky, 1994; Bamforth, 1986; Binford, 1979; Gould, 1980; Kuhn, 1992; Macdonald, 2009; Parry \& Kelly, 1987; Riel-Salvatore \& Barton, 2004; Torrence, 1983), we can expect a different treatment of rocks across these categories-ultra-local, $<1 \mathrm{~km}$; local, 1-10 km; and non-local, $>10 \mathrm{~km}$-involving different levels of activity and distinct behavioral patterns. The procurement of local rocks during hunting and gathering trips can be contrasted with the acquisition of raw materials from the residential site (Binford, 1979, 1980; Kelly, 1983). The latter would require little effort and can be done while performing other domestic tasks such as tending to fire, caring for children, or manufacturing tools. While these practices are embedded into daily tasks, they require different levels of energy, mobility, and planning in a system of distinct activities.

Due to their coarse-grained nature, artifacts from rock types such as sandstone or calcrete express knapping attributes differently from fine-grained cherts or flints. Assemblages from these raw materials might appear at first glance to feature mostly amorphous pieces with little secondary modifications. As a result, they are frequently neglected or not even recognized as anthropogenic, particularly when also forming the substrate of archaeological sites. Similar considerations for vein quartz (referred to as "quartz" in this article) have led to calling this phenomenon "gravel effect" (Callahan, 1987), emphasizing the difficulty for archaeologists to study these raw materials and identify human-made artifacts (see also the experiment by Driscoll, 2011a). Quartz has specific fracture mechanics that lead to different expressions of knapping attributes. While quartz produces sharp edges when flaked, its heterogeneous composition, internal flaws, and tendency to shatter make the fracture propagation difficult to predict. Furthermore, vein quartz tends to break along crystal boundaries and often does not exhibit conchoidal fracture (Driscoll, 2010; Knight, 1991; Knutsson, 1998; Tallavaara et al., 2010). The special properties of these rock types might not only have influenced the technological choices of past humans but also require different analytical methodologies by today's researchers (see above "flint thinking"; Callahan, 1987; Driscoll, 2010; Knight, 1991; Knutsson, 1998, 2014; Hawkins \& Mosig Way, 2020; Manninen, 2016; Terradillos-Bernal \& Rodríguez-Álvarez, 2017).

Here, I am interested in how knappers approached raw materials, such as calcrete and sandstone, compared to other finer-grained, often non-local, rock types, such as silcrete or hornfels with potential higher knapping suitability, across different spatio-temporal contexts and distinct site types during the MSA. My comparative 
raw material analyses draw on materials from the open-air special-purpose camp of HDP1 (Western Cape) and the rockshelter residential site of Sibudu (KwaZulu-Natal). These important MSA localities derive from modern excavations and provide excellent case studies from different occupation types and temporal contexts $(\sim 130-100 \mathrm{ka}$ and $\sim 58 \mathrm{ka}$, respectively). They provide opportunities to evaluate the technological and techno-economic role of these raw materials, as well as their relevance in site-use behavior and general settlement strategies. The approach followed here is predominantly inductive and exploratory. Yet, previous studies on MSA lithic assemblages and general work on the organization of lithic technology provide the expectation of a marked distinction for the role of these raw materials based on their knapping suitability and availability. I first assess these expectations at the case study sites and then more broadly for the MSA of southern Africa, and in closing discuss how lithic analysts might need to adjust their methods when studying assemblages dominated by sandstone or quartz.

\section{Material and Methods}

In order to test the role of different raw materials at HDP1 and Sibudu, I compare assemblages from coarser-grained (ultra-local) and finer-grained (nonlocal) rock types, adding locally procured quartz and its specific fracture mechanics as an additional test case. For HDP1, these categories consist of calcrete (ultra-local), quartz (local), and silcrete (nonlocal), whereas for Sibudu, they include sandstone (ultra-local), quartz (local), and hornfels (nonlocal). The leading questions are:

1. Were coarser-grained, local raw materials treated differently from finer-grained, non-local rock types?

2. What is the function of raw material of presumed low knapping suitability in the lithic assemblages?

3. Do HDP1 and Sibudu differ in their approach to such raw materials?
Subsequently, these results are put in the wider regional context of the southern African MSA alongside general analytical considerations.

HDP1 is an open-air locality deposited under a calcrete carapace of a fossilized dune and situated on the Atlantic coastline of South Africa, about $110 \mathrm{~km}$ north-northwest of Cape Town (Fig. 1). The archaeological site yielded stratified deposits of MSA artifacts associated with shellfish remains. A joint team from the University of Tübingen and Cape Town excavated the archaeological deposits in 2011 and exposed a maximal thickness of 1.5-m deposits. The HDP1 sequence consists of three consecutive archaeological horizons (AH I-III) in primary context (Will et al., 2013). Each layer contains lithic artifacts, ocher, terrestrial fauna, shellfish, and ostrich eggshell. The lithic assemblages used in this study derive from these three main archaeological horizons. Previous and recent datings by optically stimulated luminescence (OSL) and TL indicate occupations between $\sim 130$ and $100 \mathrm{ka}$ (Tribolo, pers. comm.; Will et al., 2013). Considering the nature and density of the archaeological deposits, we interpreted the site as a temporary locale for exploiting marine resources, with repeated, short-term stays by small and mobile hunter-gatherer groups rather than large-scale and long-term occupations (Will et al., 2013, 2015).

In contrast, the archaeological deposits at Sibudu consist of rich and dense accumulations of anthropogenic material that reflect long-term use in the context of a residential site. The very large sandstone rockshelter, measuring $55 \mathrm{~m}$ in length and about $18 \mathrm{~m}$ in width, overlooks the uThongathi River in KwaZulu-Natal, South Africa, about $40 \mathrm{~km}$ north of Durban and $15 \mathrm{~km}$ from the Indian Ocean (Fig. 1). From 1998 until 2011, Lyn Wadley directed 25 field seasons of excavation at Sibudu. Her team excavated MSA deposits over an area of $21 \mathrm{~m}^{2}$ to a depth of up to $3 \mathrm{~m}$. This sequence dates between $<75$ and $37 \mathrm{ka}$ and encompasses, in Wadley's nomenclature, the pre-Still Bay, Still Bay, post-Howiesons Poort, late MSA, and final MSA strata (Jacobs et al., 2008; Wadley, 2013; Wadley \& Jacobs, 2006). Archaeological work at Sibudu since 2011 directed by N. Conard has focused on re-excavating the upper portion of the MSA sequence beginning at the top of the "post- Howiesons Poort (HP)" or Sibudan. This Sibudan sequence lies below the "late MSA" and on top of the Howiesons Poort. The depositional 

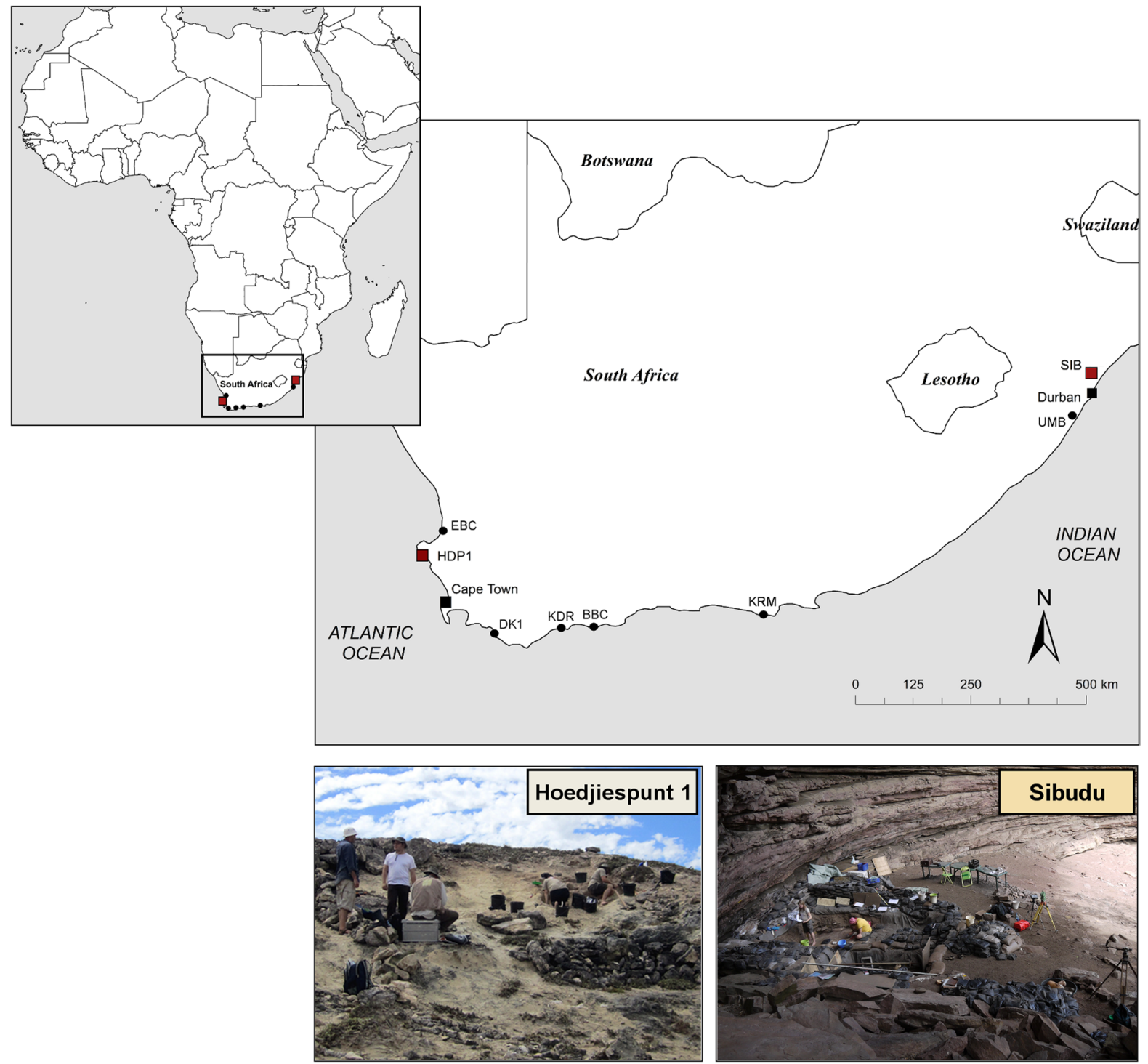

Fig. 1 Geographical location and site view for Hoedjiespunt 1 (HDP1) and Sibudu (SIB) in relation to other comparative localities. Abbreviations: UMB, Umbeli Belli; KRM, Klasies

sequence of $1.2 \mathrm{~m}$ thickness includes a succession of 23 finely laminated find horizons, which are often centimeter thin (Goldberg et al., 2009; Miller, 2015; Will \& Conard, 2018). This sequence has an extraordinarily high temporal resolution for the Stone Age, with occupations at the base, middle, and top of the deposits dated to $\sim 58 \mathrm{ka}$ by OSL. Combined, these observations attest to multiple intense and repeated occupations by MSA hunter-gatherers over a couple of centuries or few millennia at most (Jacobs et al.,
River Mouth; BBC, Blombos Cave; KDR, Klipdrift Rockshelter; DK1, Die Kelders 1; EBC, Elands Bay Cave

2008; Wadley \& Jacobs, 2006). The archaeological assemblages included here derive from the 23 layers of the Sibudan or "post-HP" whose techno-typological characteristics have been published in detail elsewhere (Conard \& Will, 2015; Conard et al., 2012; Will, 2019; Will \& Conard, 2018; Will et al., 2014).

Regarding statistical methods for the quantitative analyses of raw materials, I calculated percentages and means to assess relative proportions and central tendencies. For tests of the association between 
specific lithic categories and archaeological layers, non-parametric Spearman's rho was used due to the scale of measurements, non-normal distributions, and $n<30$ (for layers). Summary statistics and more advanced analyses were performed using Microsoft Excel 2019 and SPSS 26.0 for Windows.

\section{Raw Materials at HDP1}

The raw materials at HDP1 can be divided into ultra-local, local, and non-local groups (Fig. 2). The existence of a thick calcrete horizon capping the site attests to an ultra-local origin of this raw material (see also Butzer, 2004; Theron et al., 1992). This sedimentary rock generally exhibits poor knapping characteristics that result in relatively blunt edges, although it becomes more predictable and shows conchoidal fracture as the degree of silicification increases. At HDP1, geogenic spalls from calcrete are, at times, intermixed with the anthropogenic sediments, complicating the identification of calcrete artifacts, particularly during the sorting of small debitage $(<20 \mathrm{~mm})$. Numeric values should thus be considered as a minimum estimate. Local raw materials make up the majority of the MSA assemblages, and these include quartz and quartz porphyry. The quartz occurs locally as veins and inclusions in the granitic bedrock (Theron et al., 1992), and most of the archaeological specimens can be classified as vein quartz (after Ballin, 2008). The majority of the vein quartz is milky white-with rarer gray, massive, opaque variants - and exhibits fracture planes. Both coarse and fine-grained variants of vein quartz are present. The rounded cortex on some artifacts indicates the use of secondary sources. In the following, I refer to all knapped variants as quartz.

Considering the regional geology (Roberts, 2003), the rock types of non-local origins consist mostly of silcrete and include varieties of chert, which are very rare at HDP1. Silcrete is more frequent and broadly defined as a sedimentary rock in which large quantities of authigenic silica have either accumulated in or replaced surface and near-surface geologic deposits to form an indurated mass (Milnes \& Thiry, 1992; Nash \& Ullyott, 2007; Summerfield, 1982). Humans across all inhabited continents used it to produce tools during the Pleistocene and Holocene (Wragg-Sykes \& Will, 2017). In southern Africa, silcrete has been described as a fine-grained siliceous rock that exhibits conchoidal fracture and produces sharp working edges but shows significant variability in its qualities due to a range of underlying formation processes. At HDP1, this raw material occurs in at least eleven distinct varieties based on macroscopic features such as grain size, texture, inclusions, fracture planes, luster, and color. We used the Diepkloof Rock Shelter Silcrete Database (Porraz et al., 2008, 2013), a catalog

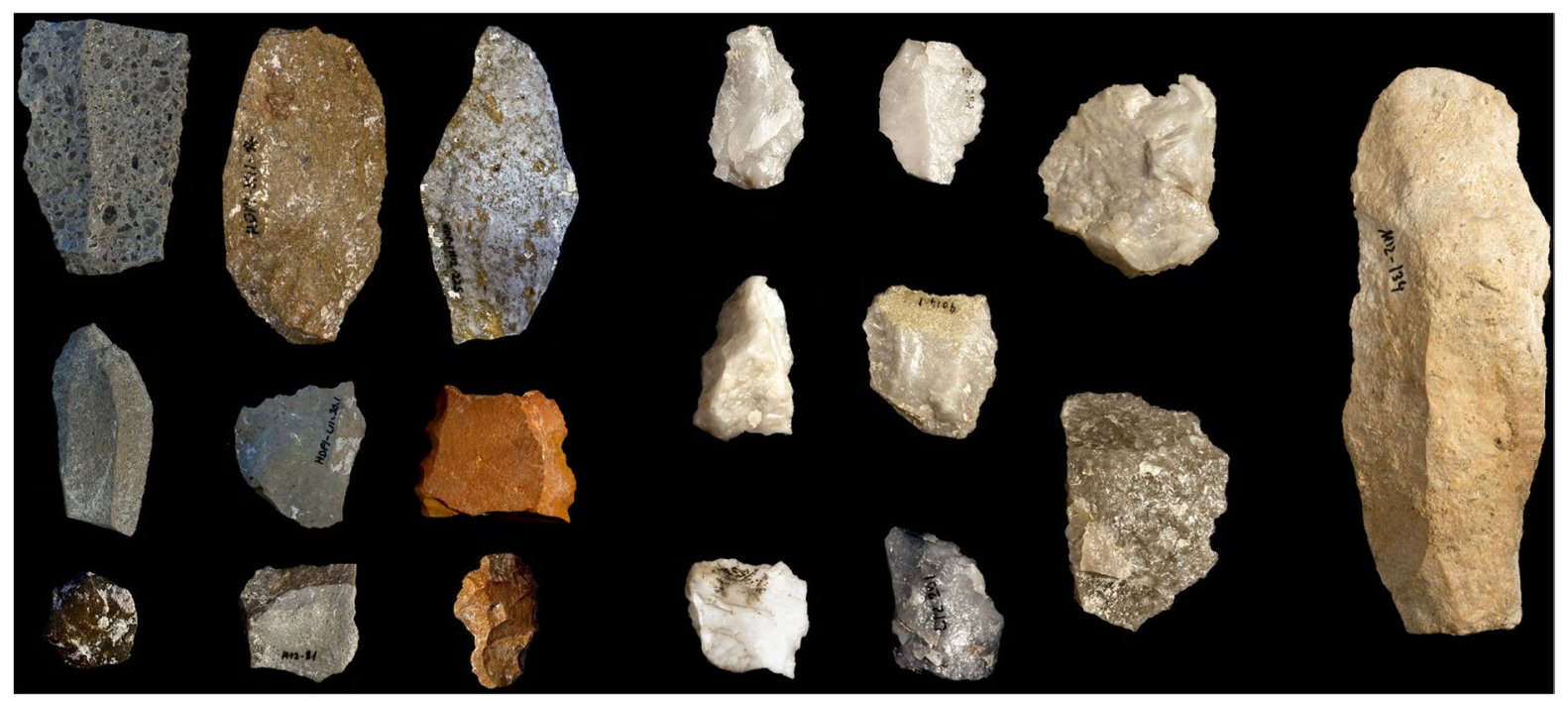

Fig. 2 Overview of selected raw materials used for knapping at HDP1. From left to right: silcrete (non-local), quartz (local), calcrete (ultra-local). Artifacts are not to scale 
of silcrete outcrops in the West Coast region, to identify the sources of the silcrete. Our comparative study found that two silcrete varieties at HDP1 correspond to four primary outcrops on the nearby Vredenburg Peninsula. The presence of outcrop cortex, which compares well with present-day exposures, and the absence of pebble cortex rule out secondary sources for these silcrete variants (Minichillo, 2005). From these observations, we established a minimum transport distance of $10-30 \mathrm{~km}$ for a third of the silcrete brought to HDP1. The source of the remaining nine silcrete varieties is unknown, possibly originating from distant locations up to $200 \mathrm{~km}$ away (Will et al., 2013).

\section{Raw Materials at Sibudu}

Knappers at Sibudu used various rock types for producing stone tools that can be divided into three categories (Fig. 3). The sandstone can be described as ultra-local, as the shelter itself is part of the Natal Group sandstones. However, the MSA inhabitants of the site occasionally used sandstones that are finer-grained than the shelter wall. The shelter sandstone is very coarse-grained with rough surfaces and frequently without conchoidal fracture patterns and concomitant knapping traces. This rock type is also challenging from an analytical perspective as sandstone pieces knapped by humans are mixed with roof spall in the archaeological sediments. In the first year of excavation, artifacts on sandstone were often not readily recognized during fieldwork and sorting. More careful consideration of these pieces and a recognition of their artifactual nature in the following years changed this situation, but a bias towards underrepresentation of sandstone artifacts in general, and particularly in the small fraction and uppermost layers, is to be expected.

Most rock types at Sibudu consist of potentially local raw materials, including dolerite, quartzite, and milky white quartz. The inhabitants of Sibudu collected most of the milky white quartz from the uThongathi River (Wadley \& Kempson, 2011). Our observations of frequent pebble cortex on quartz support this assertion. Non-local raw materials are mainly represented by hornfels (metamorphosed shale), with rare pieces of jasper and crypto-crystalline silicates (CCS). Hornfels constitutes the finest-grained material used at Sibudu. It is darkgray to black, dense, and massive, and it has high silica content. The hornfels shows favorable knapping characteristics with a clear conchoidal fracture and produces sharp but delicate and fragile edges. Today, hornfels of the quality found in the MSA assemblages is not present in the direct vicinity of Sibudu. The closest known outcrop of hornfels occurs in the Verulam area, 15-20 km south of the site (Wadley \& Kempson, 2011). Hornfels rarely appears in the form of pebbles in the uThongathi river, and most of the cortex on the archaeological

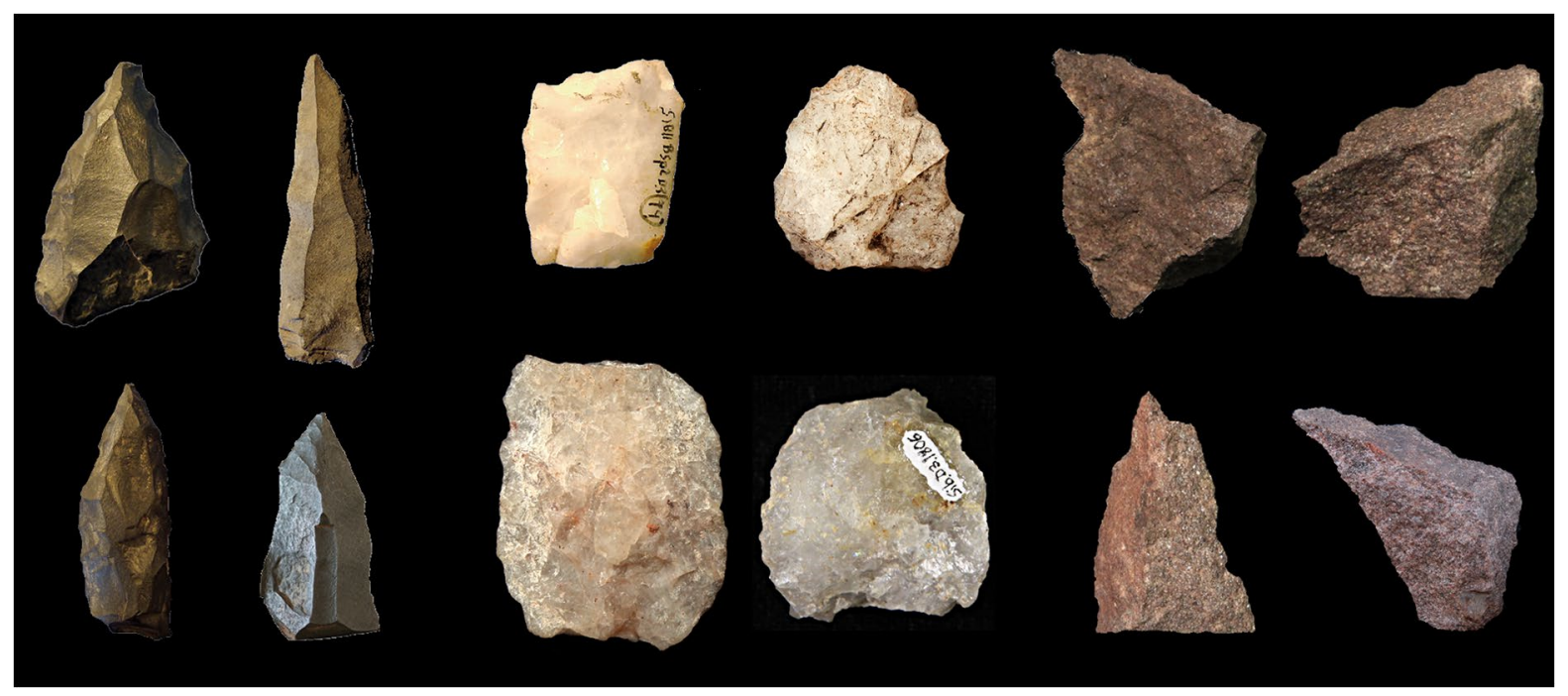

Fig. 3 Overview of selected raw materials used for knapping at Sibudu. Artifacts are not to scale. From left to right: hornfels (nonlocal), quartz (local), sandstone (ultra-local) 
specimens indicates a primary origin in the form of slabs.

\section{Results}

Procurement and Representation of Raw Materials

The raw material distribution at HDP1 shows the dominance of local quartz (80.2\%) and almost equal occurrence of ultra-local calcrete (7.2\%) and nonlocal silcrete $(6.4 \%)$ for pieces $>20 \mathrm{~mm}$ (Table 1). For silcrete, there are several varieties that only occur as a single artifact and mostly less than five pieces. Quartz dominates in all layers but varies between $61 \%$ and $91 \%$; calcrete fluctuates 3-12\%, and silcrete 4-12\% (Fig. 4). Interestingly, the proportions of calcrete and silcrete are almost equal in all assemblages and appear to be mostly influenced by the overall abundance of quartz. When using weight instead of piece count, taking into account the higher tendency to break for quartz compared to other raw materials, the overall proportion for quartz decreases (to 75\%), but only slightly. When looking at the two size categories among the small debitage $(<20 \mathrm{~mm})$ distinguished at HDP1, artifacts $0-10 \mathrm{~mm}$ and $11-20 \mathrm{~mm}$ are even more strongly dominated by quartz $(97.9 \%$ and $88.8 \%)$, with much lower values for calcrete $(0.1 \%, 6.3 \%)$, and particularly for silcrete $(0.1 \%$, $2.3 \%)$. In both size categories of the small fraction, there is thus an underrepresentation of silcrete. In terms of their artifact representation, quartz shows all products of the reduction sequence with a focus on unretouched blank production and the highest incidence of angular debris (12\%). Silcrete and calcrete both feature few cores $(\sim 1 \%)$, with silcrete having the highest abundance of retouched pieces among all raw materials $(8 \%)$ and calcrete the lowest (1\%). Calcrete artifacts are mostly non-modified blanks (90\%).

The Sibudan assemblages at Sibudu feature overall $14.9 \%$ of ultra-local sandstone, $3.5 \%$ of local quartz, and $10 \%$ of non-local hornfels for pieces $>30 \mathrm{~mm}$ (Table 1 ). This larger cutoff point for individual finds was chosen at Sibudu, compared to $20 \mathrm{~mm}$ for HDP1, due to the high number of finds. There are major diachronic differences in the use of raw materials throughout the sequence (Fig. 4). Sandstone is the dominant raw material in the lowermost Sibudan layers (RB-YA2: 29-51\%), frequent in the middle (YA-SP: $14-46 \%$ ), and rare in the upper part (SU-BSP: 1-5\%). Quartz shows comparable trends with higher frequencies in the bottom ( 17-27\%), fewer in the middle (6-14\%), and almost none at the top $(0-1 \%)$. Finally, hornfels exhibits a mirror image of these trends, being frequent at the top (6-38\%), almost absent in the middle (0-1\%), and rare at the very bottom (2-6\%). Using weight instead of piece count increases the figures for sandstone even more (proportion up until $67 \%$ ) but slightly reduces the maximum amounts of hornfels (25\%) and quartz (24\%).

Looking further into these diachronic trends by layers, there is a significant and negative correlation between hornfels and sandstone (Spearman's rho $=-0.661, p=0.001, n=23$ ) and hornfels and

Table 1 Distribution of raw materials $(n)$ at HDP1 and Sibudu, showing the different size cutoffs for single finds and small debitage

\begin{tabular}{llll}
\hline Raw material & Single finds & Small debitage & Microdebitage \\
\hline $\begin{array}{l}\text { Hoedjiespunt } 1 \\
\left(18 \mathrm{~m}^{2} \text { excavated }\right)\end{array} \quad$ Calcrete & $>\mathrm{mm}$ & $10-20 \mathrm{~mm}$ & $<10 \mathrm{~mm}$ \\
$\quad$ Quartz & 87 & 84 & 37 \\
$\quad$ Silcrete & 972 & 1188 & 164 \\
& 78 & 30 & 4 \\
Sibudu & $>30 \mathrm{~mm}$ & $10-30 \mathrm{~mm}^{*}$ & $<10 \mathrm{~mm}^{* *}$ \\
$\left(6 \mathrm{~m}^{2}\right.$ excavated $)$ & & & 539 \\
$\quad$ Sandstone & 1682 & 3925 & 219 \\
$\quad$ Quartz & 534 & 2242 & 1711 \\
$\quad$ Silcrete & 1127 & 1544 & \\
\hline
\end{tabular}

\footnotetext{
*Sampled from 17 layers in $1 \mathrm{~m}^{2}$

** Sampled from 11 layers in $1 \mathrm{~m}^{2}$
} 

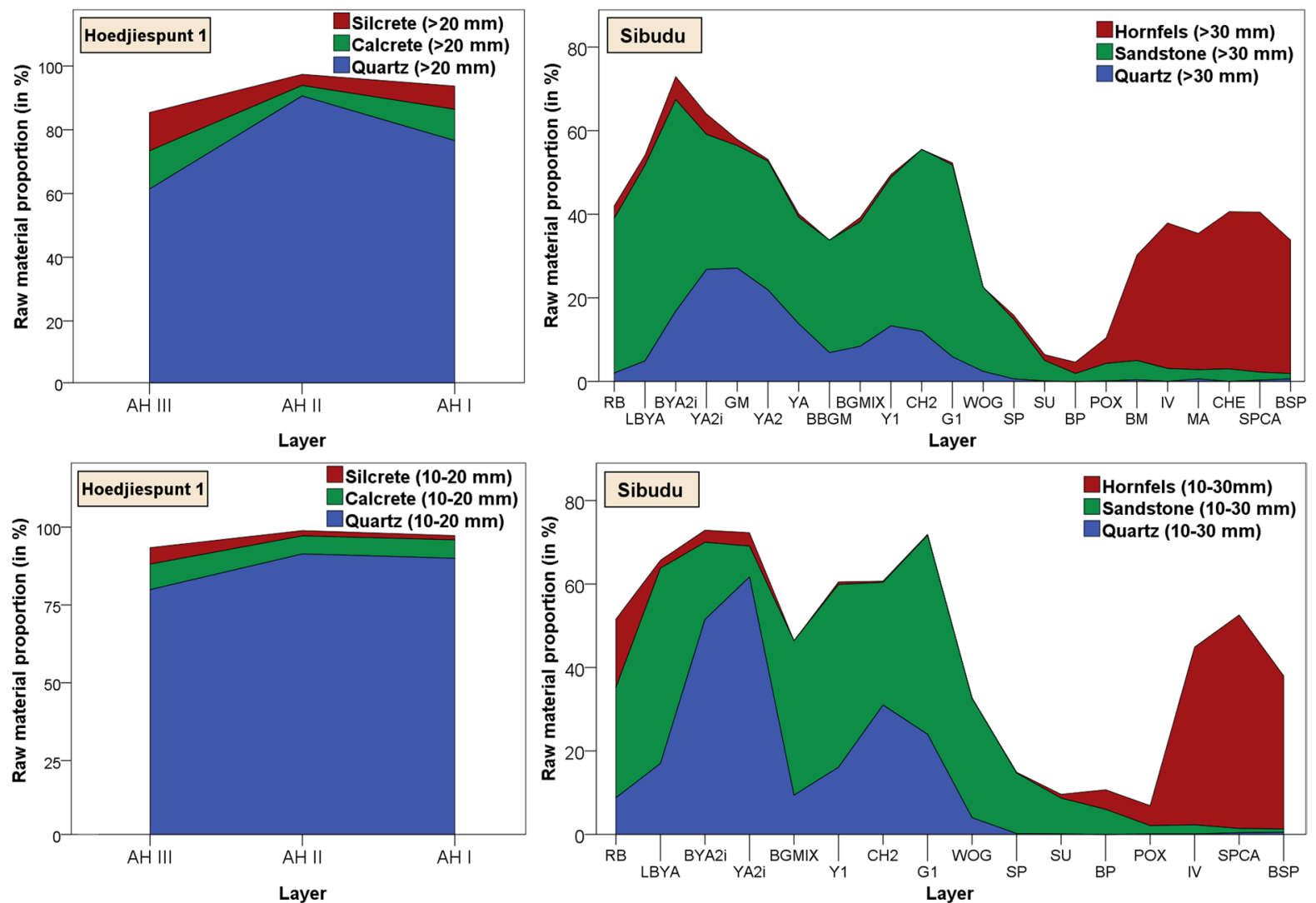

Fig. 4 Proportion of selected raw materials (in \%) for HDP1 (left) and Sibudu (right) among all raw materials per layer. Note the different size cutoffs for the categories at HDP1 and Sibudu

quartz (Spearman's rho $=0.455, p=0.029, n=23$ ). While quartz is only well represented where sandstone is present, there are several occupations during which sandstone played an important quantitative role without large proportions of quartz. Samples of smaller debitage products $(10-30 \mathrm{~mm})$ provide similar trends, with a higher proportion of quartz, $61.7 \%$ in the lower layers (in the upper part $<1 \%$ ), being the most abundant raw material in BYA2i and YA2i (Fig. 4). Sandstone has a peak frequency of $47.7 \%$ and is again dominant in the middle and lower sequences. Hornfels never reaches more than 5\% except in the uppermost layers, becoming the most abundant raw material in SPCA $(51.2 \%)$. Regarding the association of raw materials with artifact classifications, an overrepresentation of retouched pieces $(27 \%)$ on hornfels stands in opposition to few tools on sandstone $(1.5 \%)$ and quartz (3\%). Most sandstone artifacts are unretouched blanks (93\%), whereas quartz has the highest representation of cores (16\%; sandstone: $0.5 \%$; hornfels: $2 \%$ ) and angular debris (7\%). Hornfels $(2 \%)$ and sandstone $(4.7 \%)$ feature lower numbers for angular debris.

Manufacture of Blanks

At HDP1, most blanks conform to flakes for all raw materials (Table 2). There is, however, a marked

Table 2 Distribution of blank types by raw material at HDP1 (data from AH I-III combined)

\begin{tabular}{llllc}
\hline Raw material & Flake $(n)$ & Flake $(\%)$ & Blade $(n)$ & Blade $(\%)$ \\
\hline Calcrete & 68 & 86.1 & 11 & 13.9 \\
Quartz & 807 & 97.9 & 17 & 2.1 \\
Silcrete & 66 & 90.4 & 7 & 9.6 \\
\hline
\end{tabular}


difference in the incidence of technological blades for calcrete (14\%) and silcrete (10\%) compared to quartz (2\%). When looking only at elongation valuesdefined as length by width of complete blanks - this pattern is repeated, with $13 \%$ of pieces having an elongation of $>2: 1$ for calcrete and silcrete and only $6 \%$ for quartz. In terms of size, pieces on silcrete are overall the longest, widest, and thickest (means: $36.7 \mathrm{~mm}, 35.1 \mathrm{~mm}$, and $8.9 \mathrm{~mm}$, respectively), with quartz being on the opposite side of the spectrum (means: $31.5 \mathrm{~mm}, 27.0 \mathrm{~mm}$, and $8.6 \mathrm{~mm}$, respectively). In their length/width and length/thickness ratio, silcrete blanks are overall the narrowest and thinnest products among the three raw materials. In terms of core technologies associated with different raw materials, there is a clear covariation between bipolar cores/products and quartz. This being said, there are also inclined (discoid), parallel (Levallois), and platform modalities on quartz. In contrast, there is only one bipolar core and one indeterminate broken core for silcrete and calcrete each. This low sample size precludes further interpretations on differences in core reduction sequences from cores alone for these rock types. The assessment of bipolar products suggests that a fourth of all quartz flakes was produced in this manner.

Regarding the orientation of dorsal negatives on the blanks at HDP1, calcrete shows mostly parallel (62\%) negatives-encompassing both unidirectional and bidirectional variants-with silcrete having both parallel $(41 \%)$ and centripetal $(20 \%)$ scars. The overall orientation of dorsal negatives points towards informal and laminar platform methods as well as some Levallois reduction for both raw materials. The knapping technique applied was the final axis of technological variation considered. Here, the main differences are a higher incidence of developed bulbs for calcrete and silcrete (52\% each) compared to quartz $(32 \%)$, likely associated with a higher incidence of bipolar reduction for the latter. Proximal lippingoverall rare at $\sim 1 \%$ for all assemblages-occurs only on silcrete $(n=5 ; 9.3 \%)$ and calcrete $(n=3 ; 4.9 \%)$ but not on quartz. Faceting of platforms is most frequent for silcrete (19\%), less for calcrete (9.8\%), and rare for quartz (1.5\%). Most quartz pieces show shattered or crushed platforms due to bipolar percussion. Platform dimensions are comparable, with platform thickness of quartz $(6.1 \mathrm{~mm})$, silcrete $(5.9 \mathrm{~mm})$, and
Table 3 Distribution of blank types by raw material in the Sibudan sequence of Sibudu

\begin{tabular}{llllc}
\hline Raw material & Flake $(n)$ & Flake $(\%)$ & Blade $(n)$ & Blade $(\%)$ \\
\hline Sandstone & 1482 & 88.1 & 53 & 3.2 \\
Quartz & 293 & 74.0 & 7 & 1.8 \\
Hornfels & 740 & 65.7 & 217 & 19.3 \\
\hline
\end{tabular}

calcrete $(5.9 \mathrm{~mm})$, all indicating internal percussion. The three rock types are comparable in the remaining knapping characteristics.

At Sibudu (Table 3), flakes are most often knapped on sandstone (88\%), less often on quartz (74\%), and even less on hornfels (66\%). In contrast, hornfels has the highest percentage of blades (19\%), more than five times the proportion of elongated products for sandstone (3\%) and quartz (2\%). Regarding overall size, sandstone blanks are the longest, heaviest, and thickest (means: $44.6 \mathrm{~mm}$, $16.3 \mathrm{~g}$, and $12.0 \mathrm{~mm}$, respectively), contrasting markedly with hornfels (means: $40.6 \mathrm{~mm}, 7.3 \mathrm{~g}$, and $6.7 \mathrm{~mm}$, respectively) and quartz (means: $34.1 \mathrm{~mm}$, $7.8 \mathrm{~g}$, and $10.1 \mathrm{~mm}$, respectively). Quartz does not feature any blanks $>60 \mathrm{~mm}$, whereas sandstone reaches $14 \%$ in this regard. There is a close association of frequent bipolar cores $(n=46)$ and quartz at Sibudu and HDP1. Hornfels occurs only on parallel and platform cores, with sandstone showing almost exclusive association with informal platform reduction. Assessing diagnostic pieces for core reduction methods on blanks yields a similar picture: Laminar products from platform cores and, to a lesser extent, Levallois flakes dominate for hornfels, whereas both categories are non-existent to rare for quartz and sandstone. Sandstone and quartz share a high frequency of expedient platform methods, but only quartz shows abundant bipolar products. Knapping traces include many developed bulbs for hornfels (43\%), associated with frequent lipping (13\%). Bulbs are rare for sandstone and quartz (19\%, $15 \%)$, as is lipping $(1.6 \%, 0.8 \%)$. Similarly, platform faceting characterizes hornfels pieces $(27 \%)$ much more than sandstone (6\%) and quartz (3\%). Quartz features frequent shattered and crushed platforms, whereas sandstone has high amounts of cortical $(14 \%)$ and plain $(47 \%)$ ones. Similar to blank 
size, platforms are the smallest for hornfels (width: $16.1 \mathrm{~mm}$; thickness: $4.8 \mathrm{~mm}$ ), followed by quartz (width: $16.3 \mathrm{~mm}$; thickness: $6.8 \mathrm{~mm}$ ) and much larger sandstone metrics (width: $22.6 \mathrm{~mm}$; thickness: $9.1 \mathrm{~mm}$ ). Platform thickness for all rock types suggests internal percussion.

\section{Assemblages of Retouched Pieces}

Retouch occurs more frequently on silcrete (8\%; $n=6)$ compared to quartz $(4 \% ; n=43)$ and calcrete $(1 \% ; n=1)$ at HDP1, but overall, the number of retouched pieces is small. The Raw Material Retouch Index (RMRI; Orton, 2008) indicates that silcrete blanks $(\mathrm{RMRI}=1.9)$ were preferentially selected over blanks from quartz $(\mathrm{RMRI}=1.04)$ and particularly calcrete $(\mathrm{RMRI}=0.27)$. Tools on quartz are more often fragmented $(64 \%)$ than silcrete and calcrete ones $(50 \%)$. In terms of tool typology, both silcrete
(83\%) and quartz (33\%) feature denticulates as the most frequent type (Fig. 5). Importantly, however, only quartz shows a range of retouched forms, also including notches (19\%), lateral retouch $(5 \%)$, and various scrapers (24\%; Table 4). There is only one slightly modified flake on calcrete. Retouch is predominantly dorsal on all raw materials. A higher tendency for selection of blades for modification characterizes silcrete (17\%) vs. quartz (5\%), albeit in a small sample.

At Sibudu, retouch is most prevalent on hornfels $(27 \% ; n=305)$, followed in far distance by quartz $(3 \% ; n=13)$ and sandstone $(1.5 \% ; n=27)$. The RMRI mirrors this picture, supporting the stark contrast between hornfels $(\mathrm{RMRI}=3.59)$ vs. quartz $(\mathrm{RMRI}=0.44)$ and sandstone $(\mathrm{RMRI}=0.21)$. A sampling of small retouch debitage throughout the sequence shows the highest prevalence of small retouch debitage occurring in hornfels and, to a lesser

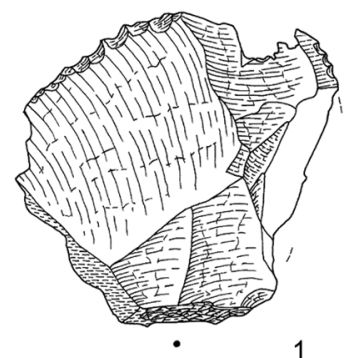

1

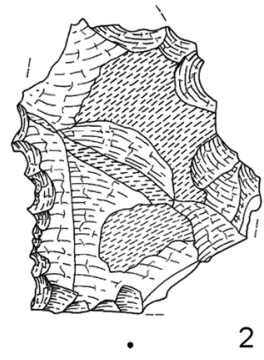

2

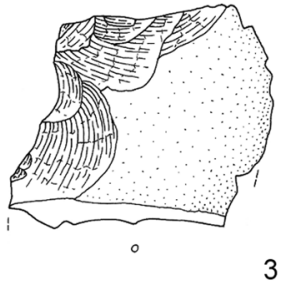

3

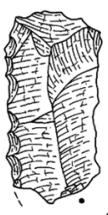

$\int_{4}$
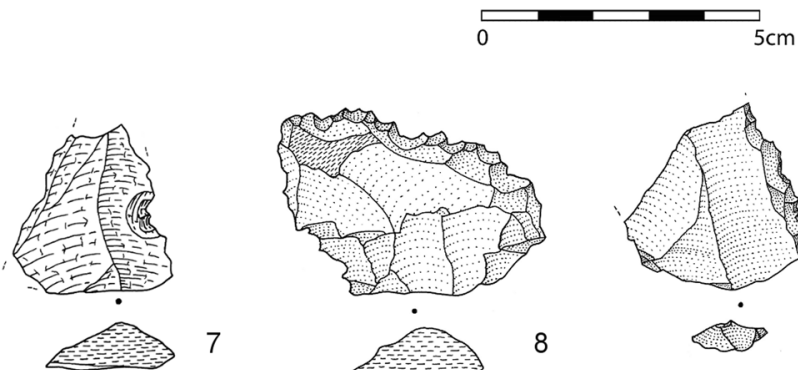

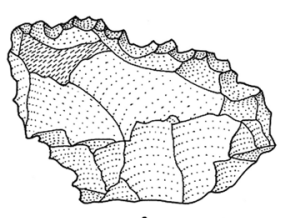

7
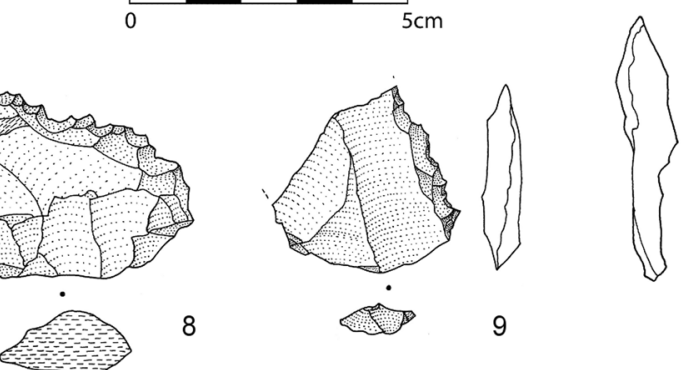
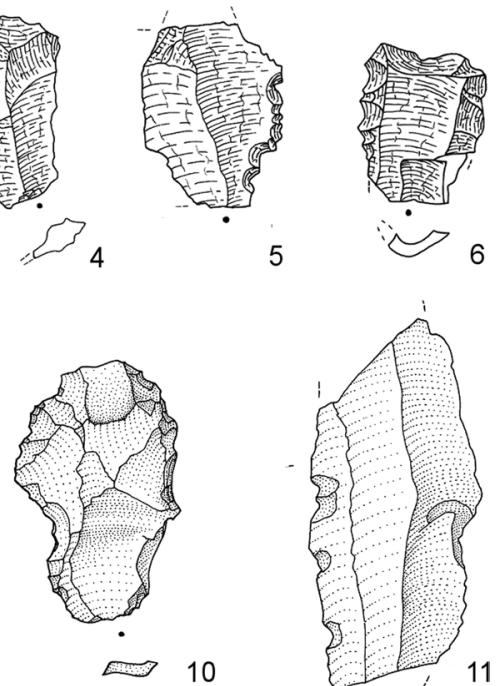

Fig. 5 Selection of typical tools on quartz and silcrete in the MSA sequence of HDP1. 1-6, quartz denticulates; 7, quartz notch; $8-11$, silcrete denticulates

Table 4 Distribution of tool types by raw material at HDP1

\begin{tabular}{llllll}
\hline Raw material & Denticulate & Notch & Scraper & Lateral retouch & Minimal retouch \\
\hline Calcrete, $n(\%)$ & 0 & 0 & 0 & 0 & $1(100)$ \\
Quartz, $n(\%)$ & $13(31)$ & $8(19)$ & $10(24)$ & $2(5)$ & $9(21)$ \\
Silcrete, $n(\%)$ & $5(83)$ & 0 & 0 & 0 & $1(17)$ \\
\hline
\end{tabular}



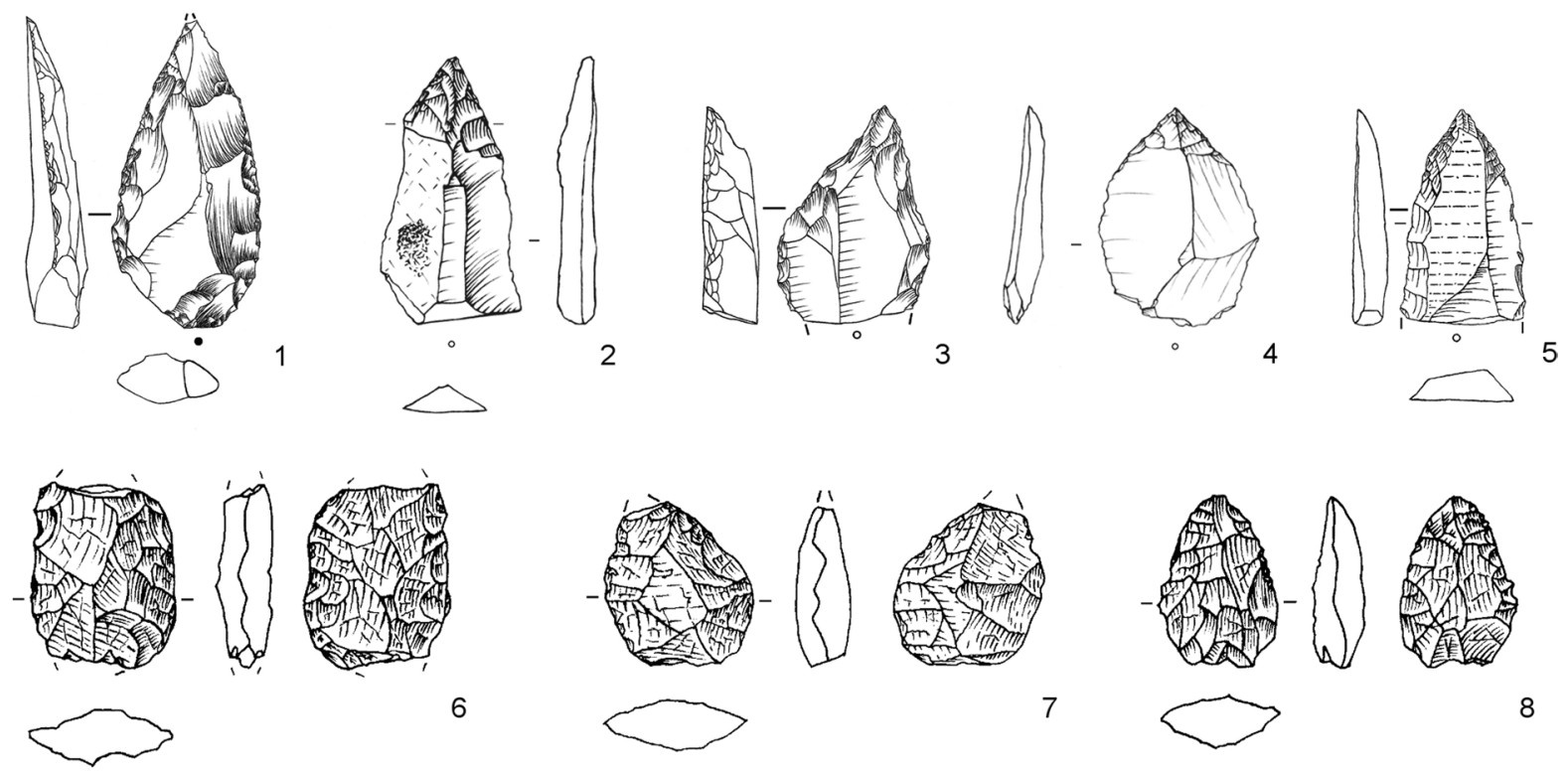

6

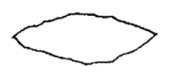

7

8
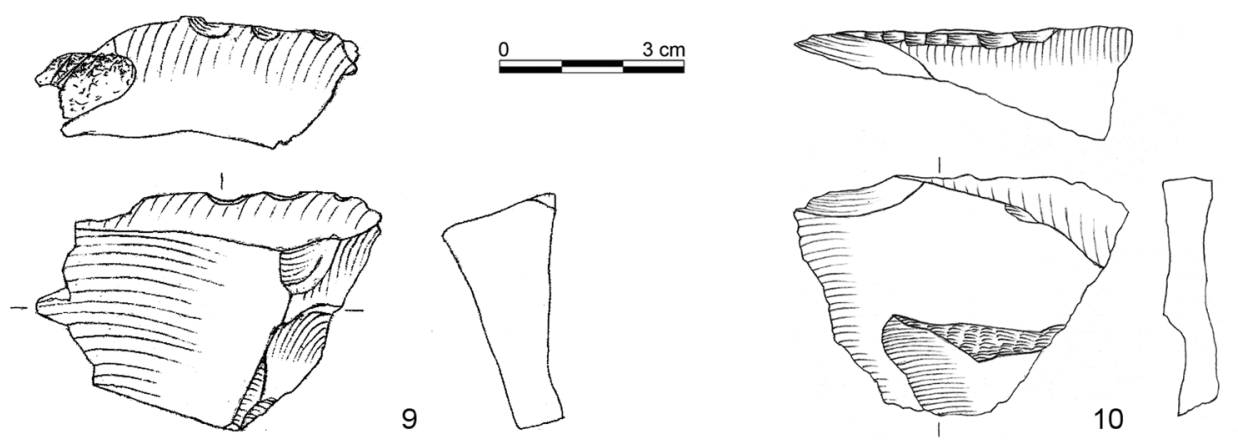

Fig. 6 Selection of typical tools on sandstone, quartz, and hornfels in the Sibudan sequence of Sibudu. 1-5, hornfels unifacial points; 6-8, quartz bifacial pieces; 9-10, sandstone scrapers

Table 5 Distribution of tool types by raw material in the Sibudan sequence of Sibudu by selected tool types

\begin{tabular}{llllll}
\hline Raw material & Unifacial point & Side scraper & Notch \& denticulate & Bifacial point & Lateral retouch \\
\hline Sandstone, $n(\%)$ & $1(4)$ & $5(18)$ & $7(25)$ & 0 & $1(4)$ \\
Quartz, $n(\%)$ & 0 & 0 & $2(14)$ & $9(64)$ & 0 \\
Hornfels, $n(\%)$ & $153(49)$ & $33(11)$ & $5(2)$ & $1(1)$ & $25(8)$ \\
\hline
\end{tabular}

Other retouched types are not included in the list (e.g., minimal retouch)

extent, in sandstone and quartz. These data attest to the on-site production of tools for all three raw materials. In terms of tool types (Fig. 6), unifacial points (49\%) dominate on hornfels, followed by scrapers $(11 \%)$ and lateral retouch $(8 \%)$; the other categories are present only in low frequency (e.g., notches and denticulates $<2 \%$; Table 5). Sandstone shows less diversity in tool types but a much higher abundance in large notches and denticulates (25\%) and scrapers (18\%). Quartz provides a different picture, with little diversity in retouch and almost exclusive production of small bifacial pieces $(64 \%)$. Changes in raw 
material abundance throughout the sequence covary with the proportion of the main tool types: unifacial points and hornfels dominate at the top of the sequence, with notches/denticulates, bifacial points, sandstone, and quartz all reaching their highest abundance in the middle and, particularly, the bottom of the deposits. This correlation is particularly significant for hornfels and unifacial points across all layers (Spearman's rho $=0.600, p=0.002, n=23$ ), and nearsignificant for sandstone and notches/denticulates (Spearman's rho $=0.390, p=0.066, n=23$ ).

\section{Raw Material Economy and Reduction Sequences}

At HDP1, silcrete and calcrete show truncated reduction sequences-with a lack of early-stage products for silcrete and no final stage elements for calcretewhereas quartz features the entire sequence of knapping events, from highly cortical pieces to retouched elements. This fits well with counts of small and retouch debitage for silcrete $(<2 \%)$ that attest to little on-site knapping. The low frequencies of calcrete small debitage are likely a result of sieving and sorting procedures (see above). Cortex patterns on quartz show a typical fall-off cure with values of $0-100 \%$ present, whereas the vast majority of silcrete products have no cortex at all $(76 \%)$ and none $>80 \%$ coverage. Regarding the number of dorsal negatives on the blanks, quartz shows less than three negatives on $80 \%$ of its flakes, attesting to short reduction sequences, often via bipolar methods. In contrast, calcrete (44\%) and silcrete $(50 \%)$ flakes frequently have three or more negatives, indicating more intense and prolonged reduction sequences.

At Sibudu, hornfels, sandstone, and quartz show mostly complete reduction sequences in layers in which they occur in higher proportions. There is, however, a tendency for hornfels to have a high representation of the distal reduction sequence, whereas sandstone and quartz feature many elements of the early manufacturing stages. This is reflected in both products and cortex cover. Hornfels has more noncortical $(71 \%)$ and fewer highly cortical (>60\% cover) pieces $(4.7 \%)$ compared to sandstone, which has $64 \%$ non-cortical and $10 \%$ highly cortical ones. In layers where hornfels has an overall abundance $<10 \%$ (e.g., POX-SP), non-cortical pieces are even higher at $73-100 \%$, suggesting import and less on-site production. In contrast, layers with frequent sandstone (e.g., YA-RB) yield higher values of cortical pieces of up to $17 \%$. On-site production for sandstone and quartz is reflected in proportions of small debitage $(10-30 \mathrm{~mm})$ reaching $>20 \%$ in the middle and bottom part of the sequence, frequencies that are sometimes even higher than for $>30$-mm products. This is particularly the case for quartz which shows an abundance of $5-27 \%$ (>30 $\mathrm{mm})$ vs. $9-62 \%(10-30 \mathrm{~mm})$ in these size categories (Fig. 4). Raw material economy at Sibudu was also measured by reduction intensity, defined by blank/core ratio, total core mass relative to total assemblage mass, and average core and flake length or thickness. In the first and second measures, lower reduction intensity is indicated for quartz (4.0 blank/core ratio; 0.229 total core mass/total assemblage mass), and also for hornfels (43.5 blank/core ratio; 0.083 total core mass/total assemblage mass), with much higher reduction intensity suggested for sandstone (218.7 blank/core ratio; 0.013 total core mass/total assemblage mass). At the same time, the initial package size was likely larger for sandstone compared to quartz and hornfels, explaining the overall larger and heavier cores and flakes for sandstone which do not match with the other indications.

\section{Discussion}

The Role of Different Raw Materials at Sibudu and Hoedjiespunt 1

This section intends to answer three main questions deriving from the lithic data of the two MSA localities in South Africa presented above: (1) Were local, coarse-grained raw materials treated differently at Sibudu and HDP1? (2) What is the function of raw materials of potentially lower suitability for knapping in the lithic assemblages and behavioral repertoire? (3) Do the special-purpose open-air site of HDP1 and the residential rockshelter locality of Sibudu differ in their approach to these raw materials? In answering these questions, hornfels (Sibudu) and silcrete (HDP1) will be used as contrasting foils, but the focus of the discussion will be on the other raw materials.

Starting with the first two questions for HDP1, knappers predominantly procured and knapped local quartz, supplementing this main rock type with equal amounts of ultra-local calcrete and non-local silcrete. In the overall representation of products, silcrete 
differs from the other rocks in the much higher amount of retouched pieces and finished blanks with multiple dorsal negatives. In a similar vein, silcrete shows truncated reduction sequences-with a lack of early-stage products. In contrast, quartz features the entire sequence of knapping events from highly cortical pieces to retouched elements, albeit with a dominance of unretouched flakes. Interestingly, the ultralocal calcrete also shows incomplete manufacturing steps in which the final stage elements are largely missing. For silcrete, the products and dorsal negative orientations indicate a more formal production method, longer use life, and transport history compared to the expedient on-site production of quartz with mostly short reduction sequences. The almost complete lack of small debitage for silcrete suggests little on-site knapping, with an import of these (larger) finished products and reduction sequences happening off-site. In contrast, quartz features very high amounts of small-sized debitage $<20 \mathrm{~mm}$, likely the result of intense on-site bipolar knapping. Importantly, however, both calcrete and quartz show some evidence for Levallois reduction as well, though in lower frequency. The tool assemblages provide an interesting picture. While there is a difference in the relative frequency of modifications between quartz and silcrete, the similar execution of retouch and the most frequent production of denticulates unite the two raw materials. In contrast, the ultra-local calcrete plays no specific role among the tool assemblages and is rarely modified in any way.

Summing up (Table 6), both quartz and calcrete differ in various dimensions from silcrete (representation of tools, size, dominant reduction method), but at the same time, quartz features similarities with silcrete (type of retouch and knapping technique) and calcrete (knapping technique and frequent unretouched flakes). Concerning overall function, the local quartz constitutes the "staple" raw material for the local tool production and use, as most of the toolrelated activities at the site were performed on this rock type. Expedient blank production for quartz can be contrasted with careful execution of retouch on the non-local, imported silcrete. Conversely, knappers used the ultra-local calcrete to produce some flakes and blades of average size, but without further modifications, potentially as a supplement and extension of the main and more durable quartz and silcrete alternatives.

In the Sibudan sequence at Sibudu, there is a clear negative covariation between local/ultra-local (quartz and sandstone) and non-local rock types (hornfels). Occupation horizons with high hornfels abundance show low quartz and sandstone prevalence and vice versa. This applies to both the small and larger fractions of stone tools. Marked differences in basic flaked products at the site characterize the three raw materials, with quartz and sandstone featuring almost exclusively flakes. Regarding knapping methods, there is a dichotomy between more formal reduction methods on non-local hornfels and more informal (expedient) reduction on sandstone and quartz. This is also associated with differences in knapping technique, with soft stone hammer percussion observed for hornfels, but not sandstone and quartz. The composition of the tool assemblages suggests a different approach regarding the production of certain implements by raw material (hornfels-unifacial points; sandstone-large, heavy-duty denticulates and scrapers; quartz-bifacial points) and an overall close connection between raw material procurement, retouching activities and functional considerations of tool use. Sandstone is characterized by large, "heavy-duty" implements with retouch aimed towards creating different edge morphologies, whereas quartz is almost exclusively

Table 6 Comparison of techno-typological characteristics of calcrete, quartz, and silcrete at HDP1

\begin{tabular}{|c|c|c|c|c|c|c|c|}
\hline Raw material & Distance & Abundance & $\begin{array}{l}\text { Blank produc- } \\
\text { tion }\end{array}$ & $\begin{array}{l}\text { Knapping tech- } \\
\text { nique }\end{array}$ & Core reduction & $\begin{array}{l}\text { Tool manufac- } \\
\text { ture }\end{array}$ & $\begin{array}{l}\text { Reduction } \\
\text { sequences }\end{array}$ \\
\hline Calcrete & Ultra-local & Rare & Flake \& blade & Hard hammer & $\begin{array}{l}\text { Expedient \& } \\
\quad \text { (formal) }\end{array}$ & $\begin{array}{r}\text { Minimal } \\
\text { retouch }\end{array}$ & $\begin{array}{l}\text { Incomplete (early } \\
\text { stage) }\end{array}$ \\
\hline Quartz & Local & Frequent & Flake & $\begin{array}{l}\text { Bipolar \& hard } \\
\text { hammer }\end{array}$ & $\begin{array}{r}\text { Bipolar \& } \\
\text { (formal) }\end{array}$ & $\begin{array}{l}\text { Denticulates \& } \\
\text { other }\end{array}$ & Complete \\
\hline Silcrete & Non-local & Rare & Flake \& blade & Hard hammer & Formal & Denticulates & $\begin{array}{l}\text { Incomplete (late } \\
\text { stage) }\end{array}$ \\
\hline
\end{tabular}


shaped into small and light points (Fig. 6). Hornfels, sandstone, and quartz show mostly complete reduction sequences in layers in which they occur in higher proportions. There is, however, a tendency for hornfels to have a strong representation of the distal reduction sequence, whereas sandstone and quartz feature many early-stage elements. For all raw materials, abundant small (retouch) debitage in layers that also have high frequencies of $>30-\mathrm{mm}$ pieces attests to combined on-site production and retouching activities.

In sum, there are some similarities in the general technology of sandstone, quartz, and hornfels in assemblages at Sibudu (Table 7), but with several differences in the modus of blank manufacture modification, and potential function. This might explain their negative covariation among the sequence, particularly in hornfels vs. sandstone/quartz. Sandstone and quartz are both local but differ strongly in their basic raw material qualities, and this is reflected in the varied reduction sequences and the different sizes and morphologies of end products. Each of these raw materials played an important part in the overall technology. Gradually, knappers replaced sandstone and quartz with hornfels for producing different kinds of blanks (blades) and implements (unifacial points), most likely reflecting different uses and changing cultural practices (Conard \& Will, 2015; Will \& Conard, 2018; Will et al., 2014).

How does the use and function of local raw materials of lower knapping suitability compare between the different site types of HDP1 and Sibudu? The most obvious start of comparison is the use of quartz in the two sequences, which in both cases is locally available. Similar provenience, quality, and package size would suggest similarities in their respective usage. Indeed, there are resemblances between the two sites concerning the presence of complete reduction sequences with the predominant production of small flakes ( 31-35 mm in length), a high abundance of small debitage products, and the most frequent use of bipolar knapping. At the same time, both HDP1 and Sibudu feature some use of more formal (e.g., Levallois) reduction on quartz. There are also a few differences. The HDP1 assemblages are "quartzdominated," whereas Sibudu features quartz mostly as a supplement to other raw materials. Yet, this can be explained by the difference in overall raw material procurement (at Sibudu, local dolerite was used for most stone tool production). A more interesting point of divergence concerns the different retouched components, with quartz showing various uses and predominant denticulates at HDP1. In contrast, Sibudu illustrates an almost exclusive production of bifacial pieces. Knappers used different retouching methods, and the final forms suggest the distinction in their respective use at each site, indicating a range of flexibility in the use of quartz during the MSA.

Another comparison can be made between the ultra-local raw materials calcrete and sandstone, both forming the immediate vicinity of each site. Calcrete appears in low abundance in the HDP1 sequence, whereas sandstone at Sibudu fluctuates from near absence to abundance, in both larger and smaller flaking products. Another difference lies in the predominant heavy-duty scraper modifications on sandstone at Sibudu, with calcrete at HDP1 showing no specific retouch patterns. Yet, there are several similarities in the low proportions of modified pieces and cores $(<2 \%)$, the application of predominantly informal

Table 7 Comparison of techno-typological characteristics of calcrete, quartz, and silcrete at Sibudu

\begin{tabular}{|c|c|c|c|c|c|c|c|}
\hline Raw material & Distance & Abundance & $\begin{array}{l}\text { Blank produc- } \\
\text { tion }\end{array}$ & $\begin{array}{l}\text { Knapping tech- } \\
\text { nique }\end{array}$ & Core reduction & $\begin{array}{l}\text { Tool manufac- } \\
\text { ture }\end{array}$ & $\begin{array}{l}\text { Reduction } \\
\text { sequences }\end{array}$ \\
\hline Sandstone & Ultra-local & Rare-frequent & Flake & Hard hammer & Expedient & $\begin{array}{l}\text { Large den- } \\
\text { ticulates \& } \\
\text { scrapers }\end{array}$ & $\begin{array}{l}\text { Complete when } \\
\text { frequent (early } \\
\text { stage) }\end{array}$ \\
\hline Quartz & Local & Rare-frequent & Flake & $\begin{array}{l}\text { Bipolar \& hard } \\
\text { hammer }\end{array}$ & $\begin{array}{r}\text { Bipolar \& } \\
\text { (formal) }\end{array}$ & Bifacial points & $\begin{array}{l}\text { Complete when } \\
\text { frequent (early } \\
\text { stage) }\end{array}$ \\
\hline Hornfels & Non-local & Rare-frequent & Blade \& flake & $\begin{array}{l}\text { Soft stone ham- } \\
\text { mer }\end{array}$ & Formal & $\begin{array}{c}\text { Unifacial points, } \\
\text { side scrapers, } \\
\text { lateral retouch }\end{array}$ & $\begin{array}{l}\text { Complete when } \\
\text { frequent (late } \\
\text { stage) }\end{array}$ \\
\hline
\end{tabular}


reduction methods with short reduction sequences, and a generally larger size of products.

All in all, local raw materials of lower knapping suitability at HDP1 and Sibudu assume many roles, from the "staple" material for all stages of manufacture and use to more special-purpose and "add-on" functions. There are also specific differences, such as the types of blanks and tools produced with these raw materials, which indicate a flexible, non-uniformist approach. Whereas expedient methods dominate these rock types, low frequencies of more formal reduction sequences could be documented for each. The ultralocal raw materials are linked in their very expedient use, likely dictated by their easy access and abundance, as expected by previous studies and general considerations from the organization of technologies by hunter-gatherers (Andrefsky, 1994; Binford, 1979; Bamforth, 1986; Gould, 1980; Kelly, 1983; Kuhn, 1991, 1992; MacDonald, 2009; Parry \& Kelly, 1987; Tomasso \& Porraz, 2016). Their much higher use in some - though not all—layers at Sibudu could provide indications for site use intensity and overall ranging patterns. As a working hypothesis, periods of longer stays at the site and reduced home ranges within the sequence correlate with more intense exploitation of the shelter wall. By implication, this would suggest that occupations at HDP1 were comparatively short, which is supported by the overall density of archaeological finds and the interpreted function of the site (Will et al., 2013, 2015). Further, sandstone assumes a specific functional role (heavy-duty tools) at Sibudu within an overall larger spectrum of activities of daily life than HDP1, where calcrete is rather a flexible and on-spot "add-on" to other raw materials, potentially due to intrinsic raw material differences (see also Terradillos-Bernal \& Rodríguez-Álvarez, 2017).

The direct comparison of purported "low quality" raw materials of local origin with fine-grained and often non-local rock types finds no black and white distinction, but a more nuanced, gradual, and flexible approach by MSA knappers with many differences but also similarities depending on the local raw material circumstances and the overall position of the sites in the settlement system. A certain appreciation for high-quality rocks can still be observed in the more frequent application of retouch and formal reduction methods, and the fact that only fine-grained rock types were imported to these MSA sites from long distances.
The Role of Different Raw Materials in the MSA of South Africa

So far, only two selected sites were compared for a detailed analysis of the use of local raw materials with lower knapping suitability and complicated fracture mechanics in the MSA of southern Africa. These localities are separated in space, time, and basic function, and the previous interpretations cannot be generalized to the entire region. To this end, I contextualize these findings based on a more superficial comparison with other sites between MIS 6 and MIS $3(\sim 160-30 \mathrm{ka})$ in South Africa to test whether the previous hypotheses and conclusions are robust for larger spatio-temporal scales and in different technological contexts. The selection of MSA sites includes different temporal snapshots from east to west: Umbeli Belli, Blombos, Klipdrift, Die Kelders, and Elands Bay Cave (Fig. 1).

Umbeli Belli is a quartzite rockshelter in KwaZulu-Natal $\sim 90 \mathrm{~km}$ away from Sibudu, featuring a detailed archaeological MSA sequence with a final MSA component dated to 32-29 ka (Bader et al., 2018). From the perspective of this article, the use of coarse-grained quartzite can be associated with ultra-local acquisition from the shelter wall. In contrast, hornfels constitutes a higher-quality raw material collected mostly from the local river pebbles. In terms of their general technology and typology, these raw materials have been treated comparably, based on the types of core reduction and production of blanks and specific bifacial tools (e.g., tear-drop shaped). Nevertheless, hornfels features much more frequently among retouched pieces, carefully shaped bifacial pieces, and bifacial shaping flakes. Also, blanks and tools are significantly thinner. The backed pieces and hollow-based points at the site are exclusively on hornfels. All in all, the many similarities among the raw materials likely derive from their similar ease of access and abundance. In contrast, the preference of hornfels in general and for all retouched products might lie in its specific knapping characteristics (see also Wadley \& Kempson, 2011).

Klipdrift rockshelter, located on the Indian coast of the southern Cape, has a high-resolution HP sequence dated to $\sim 66-59 \mathrm{ka}$, and its lithic assemblages were recently analyzed in detail (see Douze et al., 2018; Henshilwood et al., 2014). The raw material situation encompasses ultra-local, coarse-grained 
quartzite from the shelter wall and local quartz and finer-grained silcrete from about $\sim 10 \mathrm{~km}$ around the site. Overall, each raw material accounts for nearly a third of the assemblages, though with many fluctuations (quartzite: $21-55 \%$; quartz: 13-65\%; silcrete: 7-46\%). Blade and Levallois cores occur on silcrete and quartz, but not quartzite. Quartzite exploitation is most expedient, with short reduction sequences performed by internal hard hammer percussion. Blades are particularly frequent for silcrete and quartz, both produced by marginal soft hammer technique but rare for quartzite with mainly flake production. As expected, the bipolar reduction is most frequent for quartz. Tools are less frequent for quartzite, which often occurs as (anthropogenic?) chunks. Various forms of backing characterize silcrete and quartz, but this kind of retouch is rare for quartzite. The mean size of backed pieces is comparable between silcrete and quartz (Douze et al., 2018, Supplement Info 1). Notched pieces and borers are confined to silcrete and quartz, unifacial points to silcrete and quartzite. Overall, silcrete shows the largest variety of tools, quartzite the lowest. There are further important diachronic shifts: an increase of quartzite in the uppermost sequence is associated with more frequent flake and less blade production. At the same time, some temporal trends are not synchronous, such as the continued production of backed pieces on various raw materials. In sum, all three raw materials at times dominate the Klipdrift HP assemblages, with silcrete and quartz showing manifold techno-typological similarities. The changes in these rock types appear to be correlated and might be interpreted as a 1:1 substitution with some specific differences (e.g., notches dominate silcrete tool assemblages, and segments dominate quartz). The coarser-grained quartzite shows several differences from these raw materials, mostly in its more expedient treatment and less-standardized and fewer retouched pieces. Yet, the uppermost layer of the HP demonstrates most blade production on quartzite, and their widths are similar to those produced on quartz and silcrete. Considering that all raw materials are locally available and that quartzite-rich occupations are generally of lower intensity, increased use of the shelter wall at Klipdrift cannot be directly associated with reduced home-range size or extended stays.

The famous Blombos cave on the Indian Ocean coast harbors a long MSA sequence, dating to 101-94 ka in main phase M3, whose lithic assemblages were analyzed in detail by Douze et al. (2015). The raw materials in this phase encompass local coarse-grained quartzite variants and quartz and finergrained silcrete that derives from non-local secondary and primary sources. Throughout the archaeological sequence, changes in silcrete negatively covary with those of quartz. When silcrete is frequent $(\sim 90 \%)$, quartz is rare $(<10 \%)$ and vice versa (e.g., layer $\mathrm{CN} /$ $\mathrm{CO}$ with $70 \%$ quartz and $<10 \%$ silcrete). Quartzite is rarely the main raw material and never occurs in large numbers $(n>100)$. Hard hammer percussion constitutes the dominant knapping technique for all raw materials. It is even applied to quartz pebbles, though the latter show infrequent traces of bipolar reduction. Products of knapping are predetermined flakes and convergent flakes for all rock types. There are, however, some variations in reduction methods and sequences by raw material: both formal and expedient core reduction methods are found for the reduction of quartz and quartzite, with silcrete featuring predominantly formal ones.

Only quartz features in all six identified reduction methods present at the site, whereas quartzite (mostly parallel methods) and silcrete (mostly parallel and inclined) only occur on half of them (see Douze et al., 2015; Fig. 5). Many tool types (e.g., notches) show no differentiation by rock type, but there is an overrepresentation of denticulates on quartzite. In accordance with contextual information, the numerically rich silcrete-dominated assemblages with full reduction sequences are interpreted as longer-time occupations by Douze et al. (2015), whereas the quartz- and quartzite-rich layers are technologically more heterogeneous and fragmented in the reduction sequences, indicative of shorter-term stays. Otherwise, no major typo-technological breaks are noted in M3, but rather gradual changes such as in the frequency of blank production methods (Douze et al., 2015). Quartz and silcrete-and to a lesser extent quartzite-assume the role of the main raw materials in different occupational circumstances and specific activities, highlighting that site use and mobility patterns were more important determinants of raw material use than mere knapping qualities. This interpretation is underscored by the fact that quartz shows similar knapping techniques and blanks produced. It also has the highest variability in reduction methods, including the main knapping technique and formal methods 
of core reduction that were likewise used on silcrete. This pattern finds further consistency in that Still Bay points in the later occupations at Blombos were made on silcrete, quartz, and quartzite alike, although silcrete is numerically the preferred rock type (Henshilwood et al., 2001; Villa et al., 2009).

Die Kelders in the Western Cape has a long MSA sequence dated to $\sim 80-60 \mathrm{ka}$ from a total of 13 layers (Grine et al., 1991; Marean et al., 2000; Thackeray, 2000). Knappers at times used the coarser-grained quartzite from the cave wall, but never $>20 \%$ in any stratigraphic unit. Local quartz and silcrete can be found as cobbles nearby and are more frequent, up to $61 \%$ for quartz and $34 \%$ for silcrete considering only assemblages $n>100$ (Thackeray, 2000). Quartz is frequently present as shatter and small debitage, potentially inflating the numerical proportion of this raw material, but no correction of this fragmentation by weight was performed. Knappers often selected silcrete for the production of elongated blanks. Blades from silcrete and quartz are shorter than those of quartzite - as are the cores-indicating their availability only as smaller nodules. Otherwise, silcrete, quartz, and quartzite were treated technologically and typologically in the same way, including formal reduction strategies and direct hard hammer percussion (Grine et al., 1991; Thackeray, 2000). Reduction sequences are mostly complete for all rock types, with the earliest stages of decortication missing. Layers rich in silcrete have a smaller sample size, potentially indicating that higher use of local quartz is also associated with longer stays at the site and reduced ranging patterns. However, both rock types are principally available at the local level. Thackeray (2000) also considers the role of flaking qualities, good workability, and sharp edges as a reason for the frequent use of silcrete at the site. Even though the proportions of quartzite, silcrete, and quartz vary strongly throughout the sequence, the main technological and typological signals remain similar. In sum, silcrete and quartz were apparently used interchangeably, with the main difference to quartzite being one of the sizes of the initial raw material package.

The early MSA occupations at Elands Bay Cave, located in the Western Cape in a quartzitic Table Mountain Sandstone cliff, provide the earliest snapshot of raw material comparisons, dating to MIS 6 (Tribolo et al., 2016). The lithic assemblages (see Schmid et al., 2016) document a nearly exclusive use of ultra-local and local quartzite (99\%) - both from the shelter wall and nearby conglomerates. Although quartz is locally available, it constitutes less than $1 \%$ of the MIS 6 assemblages. Non-local silcrete $(>20 \mathrm{~km}$ transport distance) occurs as three isolated pieces. Large slabs and flakes were used at the site to manufacture predominantly small flakes, mostly without retouching. Cortex occurs on almost all of these pieces $(85 \%)$, and reduction sequences are complete. Based on the techno-typological characteristics of the assemblages and the homogeneity of the raw materials, the assemblages have been interpreted as a quarry site, a lag deposit, or an occupation with diverse activities focused on blank production (Schmid et al., 2016). In any case, procurement costs were minimal, and knappers during the occupations at Elands Bay Cave in MIS 6 preferred quartzite over any other available rock type for their main flaking purposes. This might be related to the specific qualities of the quartzite: knappers exploited the natural plain surfaces and frequent right angles of the raw material via a specific core reduction strategy adapted to this geometry (Schmid et al., 2016). The near-exclusive use of quartzite is interesting from a diachronic perspective, as later MSA occupations at the site at $36-30 \mathrm{ka}$ (Porraz et al., 2016) show almost exclusive use of quartz (79-97\%) with frequent bipolar percussion, followed by some quartzite $(0-14 \%)$ and silcrete $(0-8 \%)$. Even in later periods and across six stratigraphic units, the purported higher-quality, non-local raw material was mostly ignored by knappers at Elands Bay Cave. Most tools are denticulates on quartz, but there are also bifacial points on this raw material. All of these assemblages are numerically small, suggesting shortterm occupations. In MIS 3, ultra-local and local rocks are frequent and were mostly reduced on-site, with non-local silcrete being mostly introduced as finished products, similar to nearby HDP1. Fitting with my hypothesis on the expected frequency of ultralocal raw materials, knappers used quartzite most frequently in layers of higher lithic densities and potentially longer stays at the site (MIS 6). This means that a reduction of this rock type and an increase of quartz and non-local silcrete occurred during shorter-term occupations (MIS 3).

Summing up the diverse observations from seven sites, the raw materials with presumed low suitability for knapping are not used in the same manner across these MSA sites in the time frame of $\sim 160-30 \mathrm{ka}$. Use 
patterns range from the "staple" and main resource on which principally all flaking activities are carried out to more special-purpose use and expedient, short, and only occasional reduction. This applies particularly to quartz, which at sites such as HDP1, Klipdrift, Die Kelders, and Blombos has been knapped and modified in principally the same manner as "high-quality" silcrete. It also applies to the ultra-local quartzite at Elands Bay Cave and, possibly, Die Kelders. The specific role of these raw materials appears to result from a combination of availability, package size, flaking properties, site use, duration of stays, settlement and procurement patterns, and intentional technological choices. Accordingly, the hypothesis of increased use of ultra-local raw materials in longer-term stays at the sites associated with reduced ranging patterns found some support at Sibudu, HDP1, and Elands Bay Cave, but not at Klipdrift and Blombos where other factors were at play. This complex web of dependencies fits expectations derived from behavioral ecology and technology of organization approaches (Andrefsky, 1994; Bamforth, 1986; Binford, 1979, 1980; Gould, 1980; Kuhn, 1992; Macdonald, 2009; Parry \& Kelly, 1987; Riel-Salvatore \& Barton, 2004; Torrence, 1983). In any case, the results presented here demonstrate that ultra-local and coarser-grained rock types can assume other functions than their often a priori assumed expedient and informal usage, depending on specific ecological and socio-cultural contexts.

The comparisons also suggest a diachronic signal with a higher prevalence of local, coarser-grained quartzite from larger package sizes in early MSA assemblages, particularly in earlier MIS 5 and MIS 6 of the Western Cape (see Mackay et al., 2014; Schmid et al., 2016; Steele et al., 2016; Will \& Mackay, 2017). A recent quantitative meta-study of all silcrete assemblages in the southern African MSA found different trends for this rock type, being particularly prevalent in MIS 4 and early MIS 3 (Will \& Mackay, 2017). The study also found a strong association of silcrete with tool manufacture and the production of backed artifacts, suggesting an influence of functional considerations and potentially cultural preferences.

Methodical Implications and Lessons for Future Lithic Analyses

Fine-grained, "glassy" rock types that exhibit conchoidal fractures and obvious knapping traces have dominated discussions of lithic technology and typology in many regions and time periods of early prehistory. "Flint thinking" (Knutsson, 1998, 2014) in Europe is one manifestation of this paradigm, which in other regions might be replaced by an "obsidian mindset" or "silcrete reasoning." This study has focused on raw materials that strongly deviate in their properties from glass on which the classic models of fracture mechanics and resulting knapping traces are based (Cotterell \& Kamminga, 1979, 1987; Cotterell et al., 1985)_raw materials such as fine-grained flint, obsidian, or basalt (e.g., Dogandžić et al., 2020). This study has some methodical implications and lessons for future lithic analyses.

Starting with the most well-researched raw material, quartz provides challenges to standard attribute analyses. Due to its tendency to break along crystal boundaries and shatter into several fragments during percussion, it has often been seen as a problematic raw material for stone knappers (see Tallavaara et al., 2010). For these reasons, quartz might need a different analytical framework when compared with other raw materials (Driscoll, 2010, 2011b; Knutsson, 1998; Knight, 1991). Yet, as Tallavaara et al. (2010, p. 2447) point out, "these differences do not mean that the same methods, such as techno-typological and aggregate analyses of debitage or use wear and reduction analyses of tools, cannot be applied [...], only that fragmentation has to be taken into account when a quartz assemblage is under study." As a general expectation, quartz artifacts will be overrepresented in numerical assessments, and their knapping traces will deviate from other raw materials. While performing attribute analysis on the quartz artifacts at Sibudu and HDP1 was possible, knapping traits were more difficult to observe, leading to higher error rates and likely reduced inter-observer reliability (see also Bisson, 1990; Cornelissen, 2003; Driscoll, 2011a; Proffitt \& de la Torre, 2014). Apart from notching, minor edge modifications on quartz are also less visible and more difficult to observe than on silcrete or hornfels (Ballin, 2008; Cornelissen, 2003; Driscoll, 2010, 2011a). What remains clear is that any quartz analysis requires an assessment of breakage, which some researchers have pursued in a more formalized strategy of "quartz fracture analysis" (Callahan et al., 1992; Knutsson, 1988). The application of such a comparative fracture analysis on the breakage patterns of tools at HDP1, for example, found that not 
all pieces were broken by use or post-depositional processes and that knappers selected flake fragments for retouch (Will et al., 2013). At HDP1 and Sibudu, quartz shows different fracture patterns compared to other raw materials and has more frequent incomplete pieces and a higher incidence of longitudinal breaks. At both sites, there is a slight overrepresentation of quartz artifacts when using the count of individual pieces, but when controlled for weight, this bias was rarely $>5 \%$. The large size cutoff for analyzing individual pieces at Sibudu $(>30 \mathrm{~mm})$ leads to a low count of these artifacts. Here, quartz shows an abundance of 5-27\% (>30 mm) vs. 9-62\% (10-30 mm). The difference between the categories in the sampled layers lies $1-35 \%$, showing that the large size cutoff point chosen at Sibudu leads to an underrepresentation of quartz, though to markedly varying degrees. As a rule of thumb, assemblages with frequent quartz pieces in the MSA ( $>50 \%$ ) should employ low or no size cutoff points, depending on the overall sample sizes, to better understand its role in the overall lithic technology.
Different analytical challenges were encountered for the ultra-local raw materials-sandstone and calcrete. These coarse-grained rocks deviate from glass fracture mechanics not so much in their overall breakage but rather in the muted manifestation or absence of typical knapping traces such as bulbs or ripples. From an analytical perspective, this results in the dual challenge of (1) distinguishing anthropogenic from geogenic pieces, particularly for small and highly fragmented pieces (Fig. 7, left side), and (2) assessing and interpreting individual attributes (Fig. 7, top right, bottom right). The first point has ramifications for excavation and sorting procedures, particularly for raw materials at archaeological sites in both forms. At HDP1 and Sibudu, calcrete and sandstone occur as geogenic input and human artifacts. At Sibudu, in particular, high amounts of sandstone spalling from the walls and roof coupled with frequent knapping of sandstone and overall high densities of lithics complicate the identification of artifacts in the field and lab (see also Schmid et al., 2019). Over the years, our team has established procedures and double checks of artifact sorting in the lab to distinguish

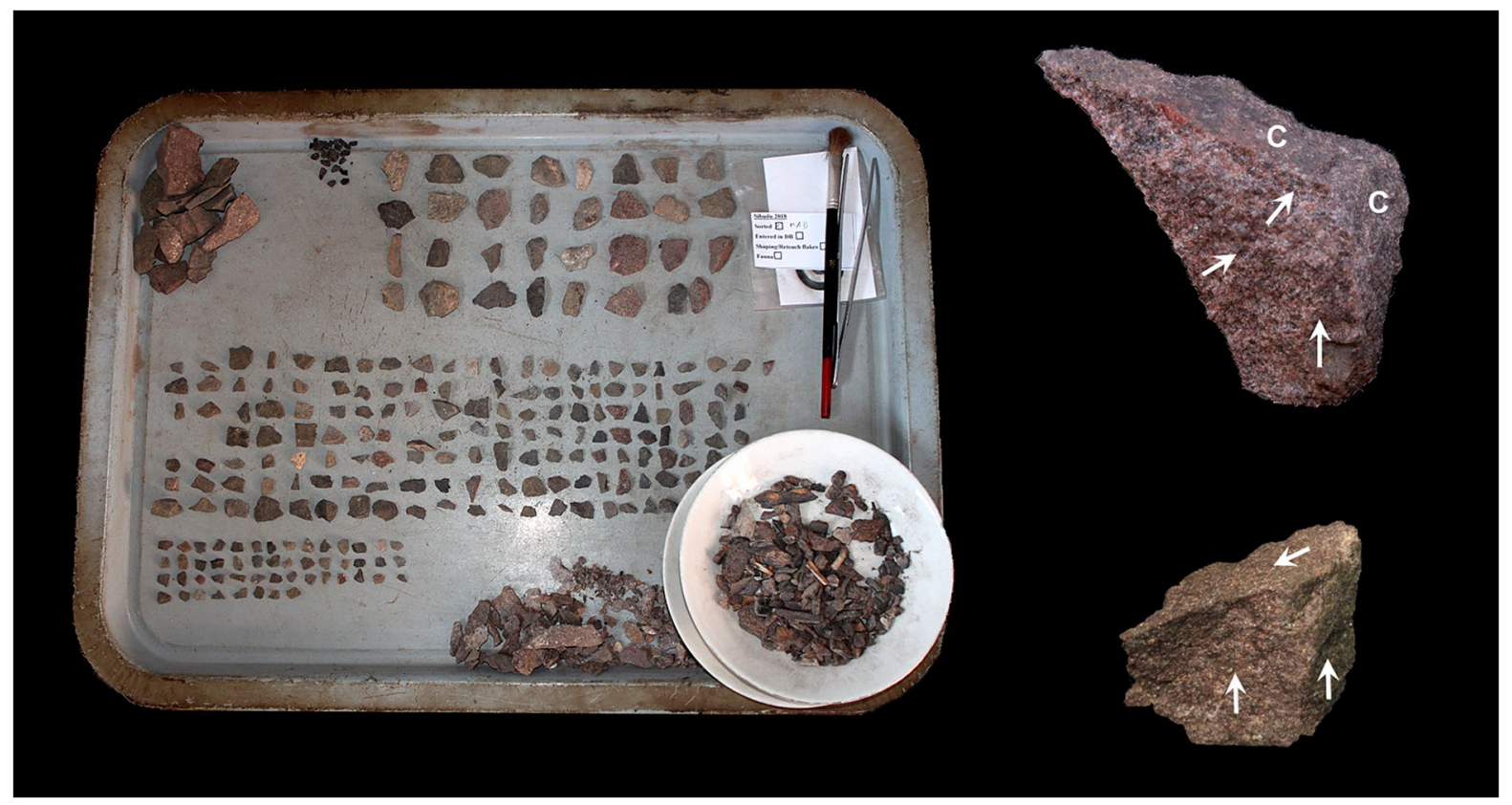

Fig. 7 Overview of artifact sorting and sandstone artifacts (not to scale) at Sibudu. Left: finished sorting tray with aligned identified lithic artifacts by size, bone fragments (bottom right, in plate), and small pieces of charcoal (top middle). Potential sandstone artifacts are separated (top left) and later examined individually by the main lithic analyst (MW). Right: two sandstone artifacts with the indication of dorsal negatives (arrows) and cortex $(\mathrm{C})$. Note the muted manifestation or lack of typical knapping traces (e.g., ripples) on the dorsal surface 
sandstone tools. Yet, for small pieces $(<10 \mathrm{~mm})$, this remains challenging even for experienced lithic analysts (Fig. 7). The same applies to quartzite artifacts at Umbeli Belli (G. Bader, personal communication), Die Kelders (Thackeray, 2000), Klipdrift (Douze et al., 2018; Henshilwood et al., 2014), and Elands Bay Cave (Butzer, 2004; Schmid et al., 2016). The proportions of such raw materials at archaeological sites should thus be considered as an approximation. In contrast, one can deduce exact numbers for raw materials introduced by humans from outside which are therefore easier to quantify.

Regarding the second point, assessing and interpreting individual attributes on such raw materials in general and in direct comparison with finer-grained raw materials requires additional time, attention, and effort by the analyst (e.g., Proffitt \& de la Torre, 2014). Particularly for less-experienced analysts and students, exposure to raw materials other than flint and other fine-grained rock types in teaching and research is crucial and requires extended time to appreciate the different manifestations of characteristics on sandstone, quartzite, and quartz. For example, establishing the order and orientation of dorsal negatives is much more complicated on sandstone than silcrete or hornfels, and it has to be done without access to information from ripples or lancet fractures. In this regard and concerning the interpretation of specific traces, more experimental studies on these raw materials - in a similar manner to the many studies that have by now been performed on flint and quartzwould greatly aid future lithic analyses (see Lengyel, 2013; Proffitt \& de la Torre, 2014; Terradillos-Bernal \& Rodríguez-Álvarez, 2017).

These analytical challenges have been known for a long time and have been specifically assessed for some raw materials (quartz in particular; Callahan et al., 1992; de la Peña \& Wadley, 2014; Driscoll, 2010; Hawkins \& Mosig Way, 2020; Knight, 1991; Knutsson, 1988; Manninen, 2016; Pargeter, 2016; Tallavaara et al., 2010). Yet, there is still a widespread tendency to either downplay methodical problems, or put less analytical emphasis on, or even ignore, artifacts and assemblages from such raw materials with presumed lower knapping suitability and different fracture mechanics. This study from the MSA of southern Africa is a reminder that while analytically challenging, these rock types are an important component of lithic technologies in many different spatial and temporal contexts and have been employed by people in a much more flexible manner than is often appreciated. Thus, a comprehensive understanding of knapping repertoires, settlement strategies, and behavioral adaptations at MSA sites requires detailed and comparative studies of all utilized raw materials.

Acknowledgements The article is dedicated to the many field and lab crews at Hoedjiespunt 1 and Sibudu, sorting through tons of stone tools, who did not despair in the face of the small debitage of calcrete and sandstone. Thank you for all your hard work and perseverance.

Funding Open Access funding enabled and organized by Projekt DEAL. The fieldwork at Sibudu has been funded by grants from the Deutsche Forschungsgemeinschaft (CO 226/28-1; CO 226/34-1; WI 4978/1-1) and through funds from the Heidelberger Akademie der Wissenschaften in the context of the long-term research project "The Role of Culture in Early Expansions of Humans."

Open Access This article is licensed under a Creative Commons Attribution 4.0 International License, which permits use, sharing, adaptation, distribution and reproduction in any medium or format, as long as you give appropriate credit to the original author(s) and the source, provide a link to the Creative Commons licence, and indicate if changes were made. The images or other third party material in this article are included in the article's Creative Commons licence, unless indicated otherwise in a credit line to the material. If material is not included in the article's Creative Commons licence and your intended use is not permitted by statutory regulation or exceeds the permitted use, you will need to obtain permission directly from the copyright holder. To view a copy of this licence, visit http://creativecommons.org/licenses/by/4.0/.

\section{References}

Ambrose, S. H., \& Lorenz, K. G. (1990). Social and ecological models for the Middle Stone Age in southern Africa. In P. Mellars (Ed.), The emergence of modern humans ( $\mathrm{pp}$. 3-33). Edinburgh University Press.

Andrefsky, W. (1994). Raw material availability and the organization of technology. American Antiquity, 59, 21-35.

Bader, G. D., Tribolo, C., \& Conard, N. J. (2018). A return to Umbeli Belli: New insights of recent excavations and implications for the final MSA of eastern South Africa. Journal of Archaeological Science, 21, 733-757.

Ballin, T. B. (2008). Quartz technology in Scottish prehistory. Scottish Archaeological Internet Reports, 26. Available from: http://www.sair.org.uk/sair26/index.html. Retrieved 6.1.2020.

Bamforth, D. B. (1986). Technological efficiency and tool curation. American Antiquity, 51(1), 38-50.

Binford, L. R. (1979). Organization and formation processes: Looking at curated technologies. Journal of Anthropological Research, 35(3), 255-273. 
Binford, L. R. (1980). Willow smoke and dogs' tails: Huntergatherer settlement systems and archaeological site formation. American Antiquity, 45, 4-20.

Bisson, M. S. (1990). Lithic reduction sequences as an aid to the analysis of Late Stone Age quartz assemblages from the Luano Spring, Chingola, Zambia. African Archaeological Review, 8, 103-138.

Brown, K. S., Marean, C. W., Jacobs, Z., Schoville, B. J., Oestmo, S., Fisher, E. C., Bernatchez, J., Karkanas, P., \& Matthews, T. (2012). An early and enduring advanced technology originating 71,000 years ago in South Africa. Nature, 491(7425), 590-593.

Butzer, K. W. (2004). Coastal eolian sands, paleosols, and Pleistocene geoarchaeology of the Southwestern Cape, South Africa. Journal of Archaeological Science, 31, 1743-1781.

Callahan, E. (1987). An evaluation of the lithic technology in middle Sweden during the mesolithic and neolithic, Aun 8. Societas Archaeologica Uppsaliensis.

Callahan, E., Forsberg, L., Knutsson, K., \& Lindgren, C. (1992). Frakturbilder. Kulturhistoriska kommentarer till det säregna sönderfallet vid bearbetning av kvarts. TOR, 24, 27-63.

Conard, N. J., Porraz, G., \& Wadley, L. (2012). What is in a name? Characterising the 'Post-Howieson's Poort' at Sibudu. South African Archaeological Bulletin, 67(196), 180-199.

Conard, N. J., \& Will, M. (2015). Examining the causes and consequences of short-term behavioral change during the Middle Stone Age at Sibudu, South Africa. PLoS One, 10(6), e0130001.

Cornelissen, E. (2003). On microlithic quartz industries at the end of the Pleistocene in Central Africa: The evidence from Shum Laka (NW Cameroon). African Archaeological Review, 20, 1-24.

Cotterell, B., \& Kamminga, J. (1979). The mechanics of flaking. In B. Hayden (Ed.), Lithic use-wear analysis (pp. 97-112). Academic Press.

Cotterell, B., \& Kamminga, J. (1987). The formation of flakes. American Antiquity, 52(4), 675-708.

Cotterell, B., Kamminga, J., \& Dickson, F. P. (1985). The essential mechanics of conchoidal flaking. International Journal of Fracture, 29(4), 205-221.

De La Peña, P., \& Wadley, L. (2014). Quartz knapping strategies in the Howiesons Poort at Sibudu (KwaZulu-Natal, South Africa). PLoS One, 9(7), e101534.

De La Peña, P., Wadley, L., \& Lombard, M. (2013). Quartz bifacial points in the Howiesons Poort of Sibudu. South African Archaeological Bulletin, 68(198), 119-136.

Dogandžić, T., Abdolazadeh, A., Leader, G., Li, L., McPherron, S. P., Tennie, C., \& Dibble, H. L. (2020). The results of lithic experiments performed on glass cores are applicable to other raw materials. Archaeological and Anthropological Sciences, 12(2), 1-14.

Douze, K., Wurz, S. \& Henshilwood, C. S. (2015). Technocultural characterization of the MIS 5 (c. 105-90 ka) lithic industries at Blombos Cave, southern Cape, South Africa. PLoS One, 10, e0142151.

Douze, K., Delagnes, A., Wurz, A., \& Henshilwood, C. S. (2018). The Howiesons Poort lithic sequence of Klipdrift
Shelter, southern Cape, South Africa. PLoS One, 13(11), e0206238.

Driscoll, K. (2010). Understanding quartz technology in early prehistoric Ireland. Ph.D. dissertation. University College Dublin, Dublin.

Driscoll, K. (2011a). Identifying and classifying vein quartz artefacts: An experiment conducted at the World Archaeological Congress, 2008. Archaeometry, 53(6), 1280-1296.

Driscoll, K. (2011b). Vein quartz in lithic traditions: An analysis based on experimental archaeology. Journal of Archaeological Science, 38, 734-745.

Féblot-Augustins, J. (1997). La circulation des matières premières au Paléolithique. Liège: E.R.A.U.L.

Goldberg, P., Miller, C. E., Schiegl, S., Ligouis, B., Berna, F., Conard, N. J., \& Wadley, L. (2009). Bedding, hearths, and site maintenance in the Middle Stone Age of Sibudu Cave, KwaZulu-Natal. South Africa. Archheological and Anthropological Sciences, 1(2), 95-122.

Gould, R. A. (1980). Raw material source areas and "curated" tool assemblages. American Antiquity, 45, 823-833.

Grine, F. E., Klein, R. G., \& Volman, T. P. (1991). Dating, archaeology and human fossils from the Middle Stone Age levels of Die Kelders, South Africa. Journal of Human Evolution, 21, 363-395.

Hawkins, R., \& Mosig Way, A. (2020). Rethinking the desirability of quartz for the manufacture of standardized retouched flakes: An example from Weereewaa (Lake George), South-eastern Australia. Lithic Technology, 45, 197-212.

Henshilwood, C. S., Sealy, J. C., Yates, R., Cruz-Uribe, K., Goldberg, P., Grine, F. E., Klein, R. G., Poggenpoel, C., Van Niekerk, K., \& Watts, I. (2001). Blombos Cave, southern Cape, South Africa: Preliminary report on the 1992-1999 excavations of the Middle Stone Age levels. Journal of Archaeological Science, 28, 421-448.

Henshilwood, C. S., van Niekerk, K. L., Wurz, S., Delagnes, A., Armitage, S. J., Rifkin, R. F., Douze, K., Keene, P., Haaland, M. M., Reynard, J. P., Discamps, E., \& Mienies, S. S. (2014). Klipdrift Shelter, southern Cape, South Africa: Preliminary report on the Howiesons Poort layers. Journal of Archaeological Science, 45, 284-303.

Jacobs, Z., Roberts, R. G., Galbraith, R. F., Deacon, H. J., Grün, R., Mackay, A., Mitchell, P., Vogelsang, R., \& Wadley, L. (2008). Ages for the Middle Stone Age of southern Africa: Implications for human behavior and dispersal. Science, 322(5902), 733-735.

Kelly, R. L. (1983). Hunter-gatherer mobility strategies. Journal of Anthropological Archaeology, 39(3), 277-306.

Knight, J. (1991). Vein quartz. Lithics, 12, 37-56.

Knutsson, K. (1988). Making and using stone tools: The analysis of the lithic assemblages from middle Neolithic sites with flint in Västebotten, northern Sweden. Societas Archaeologica Upsaliensis.

Knutsson, K. (1998). Convention and lithic analysis. In L. Holm \& K. Knutsson (Eds.), Proceedings from the Third Flint Alternatives Conference at Uppsala, Sweden, October 18-20, 1996. Occasional Papers in Archaeology, 16, 71-93.

Knutsson, K. (2014). 'Simple' need not mean 'archaic.' Antiquity, 88(341), 950-953. 
Kuhn, S. L. (1991). "Unpacking” reduction: lithic raw material economy in the Mousterian of west-central Italy. Journal of Anthropological Archaeology, 10, 76-106.

Lengyel, G. (2013). Knapping experiments on lithic raw materials of the Early Gravettian in Hungary. In Z. Mester (Ed.) The lithic raw material sources and interregional human contacts in the Northern Carpathian regions (pp. 39-51). Polska Akademia Umiejętności.

Kuhn, S. L. (1992). On planning and curated technologies in the Middle Paleolithic. Journal of Anthropological Research, 4, 185-214.

Kuhn, S. L. (1994). A formal approach to the design and assembly of mobile toolkits. American Antiquity, 59, 426-442.

Lombard, M., Wadley, L., Deacon, J., Wurz, S., Parsons, I., Mohapi, M., Swart, J., \& Mitchell, P. (2012). South African and Lesotho Stone Age sequence updated. South African Archaeological Bulletin, 67, 123-144.

MacDonald, D. H. (2009). Understanding decision-making among prehistoric hunter-gatherers via the study of lithic technological organization. Lithic Technology, 34, 71-92.

Mackay, A., Stewart, B. A., \& Chase, B. M. (2014). Coalescence and fragmentation in the Late Pleistocene archaeology of southernmost Africa. Journal of Human Evolution, 72, 26-51.

Manninen, M. A. (2016). The effect of raw material properties on flake and flake-tool dimensions: A comparison between quartz and chert. Quaternary International, 424, 24-31.

Marean, C. W., Goldberg, P., Avery, G., Grine, F. E., \& Klein, R. G. (2000). Middle Stone Age stratigraphy and excavations at Die Kelders Cave 1 (South Africa): The 1992, 1993, and 1995 field seasons. Journal of Human Evolution, 38, 7-42.

McCall, G. S. (2007). Behavioral ecological models of lithic technological change during the later Middle Stone Age of South Africa. Journal of Archaeological Science, 34(10), 1738-1751.

Miller, C. E. M. (2015). High-resolution geoarchaeology and settlement dynamics at the Middle Stone Age sites of Diepkloof and Sibudu, South Africa. In N. J. Conard \& A. Delagnes (Eds.), Settlement dynamics of the Middle Paleolithic and Middle Stone Age (Vol. IV, pp. 27-46). Kerns Verlag.

Milnes, A. R. \& Thiry, M. (1992). Silcretes. In I. P. Martini \& W. Chesworth (Eds.), Weathering, soils and palaeosols. Developments in Earth surface processes 2 (pp. 349-377). Elsevier.

Minichillo, T. J. (2005). Middle Stone Age lithic study, South Africa: An examination of modern human origins. Ph.D. dissertation. University of Washington, Washington.

Mourre, V., Villa, P., \& Henshilwood, C. S. (2010). Early use of pressure flaking on lithic artifacts at Blombos Cave. South Africa. Science, 330(6004), 659-662.

Nash, D. J., \& Ullyott, J. S. (2007). Silcrete. In D. J. Nash \& S. J. McLaren (Eds.), Geochemical sediments and landscapes (pp. 95-143). Wiley-Blackwell.

Nelson, M. C. (1991). The study of technological organization. Journal of Archaeological Method and Theory, 3, 57-100.
Orton, J. (2008). A useful measure of the desirability of different raw materials for retouch within and between assemblages: The raw material retouch index (RMRI). Journal of Archaeological Science, 35(4), 1090-1094.

Pargeter, J. (2016). Lithic miniaturization in Late Pleistocene southern Africa. Journal of Archaeological Science: Reports, 10, 221-236.

Parry, W. J., \& Kelly, R. L. (1987). Expedient core technology and sedentism. In J. K. Johnson \& C. Morrow (Eds.), The organization of core technology (pp. 285304). Westview Press.

Porraz, G., Schmid, V. C., Miller, C. E., Tribolo, C., Cartwright, C. R., Charrié-Duhaut, A., Igreja, M., Mentzer, S. M., Mercier, N., Schmidt, P., Conard, N. J., Texier, P. J., \& Parkington, J. (2016). Update on the 2011 excavation at Elands Bay Cave (South Africa) and the Verlorenvlei Stone Age. South African Humanities, 29, 33-68.

Porraz, G., Texier, P.-J., Archer, W., Piboule, M., Rigaud, J.-P., \& Tribolo, C. (2013). Technological successions in the Middle Stone Age sequence of Diepkloof Rock Shelter, Western Cape, South Africa. Journal of Archaeological Science, 40(9), 3376-3400.

Porraz, G., Texier, P.-J., Rigaud, J.-P., Parkington, J., Poggenpoel, C., \& Roberts, D. L. (2008). Preliminary characterization of a Middle Stone Age lithic assemblage preceding the 'classic' Howieson's Poort complex at Diepkloof Rock Shelter, Western Cape Province, South Africa. South African Archaeological Society Goodwin Series, 10, 105-121.

Proffitt, T., \& de la Torre, I. (2014). The effect of raw material on inter-analyst variation and analyst accuracy for lithic analysis: A case study from Olduvai Gorge. Journal of Archaeological Science, 45, 270-283.

Riel-Salvatore, J., \& Barton, M. (2004). Late Pleistocene technology, economic behavior, and land-use dynamics in southern Italy. American Antiquity, 69, 257-274.

Rios-Garaizar, J. (2016). Early Middle Palaeolithic occupations at Ventalaperra cave (Cantabrian Region, Northern Iberian Peninsula). Journal of Lithic Studies, 3(1), 161-183.

Roberts, D. L. (2003). Age, genesis, and significance of South African coastal belt silcretes. Memoir 95. Council for Geoscience, Pretoria.

Rots, V., Lentfer, C., Schmid, V. C., Porraz, G. \& Conard, N. J. (2017). Pressure flaking to serrate bifacial points for the hunt during the MIS5 at Sibudu Cave (South Africa). PLoS One, 12(4), e0175151.

Schmid, V. C., Conard, N. J., Parkington, J., Texier, P.-J., \& Porraz, G. (2016). The 'MSA 1' of Elands Bay Cave (South Africa) in the context of the southern African Early MSA technologies. South African Humanities, 29, 153-201.

Schmid, V. C., Porraz, G., Zeidi, M., \& Conard, N. J. (2019). Blade technology characterizing the MIS 5 D-A layers of Sibudu Cave. South Africa. Lithic Technology, 44(4), 199-236.

Schmidt, P., Porraz, G., Slodczyk, A., Bellot-Gurlet, L., Archer, W., \& Miller, C. E. (2013). Heat treatment in the South African Middle Stone Age: Temperature induced transformations of silcrete and their technological implications. Journal of Archaeological Science, 40(9), 3519-3531. 
Singer, R., \& Wymer, J. J. (1982). The Middle Stone Age at Klasies River Mouth in South Africa. The University of Chicago Press.

Steele, T. E., Mackay, A., Fitzsimmons, K. E., Igreja, M., Marwick, B. \& Orton, J. (2016). Varsche Rivier 003: A Middle and Later Stone Age site with Still Bay and Howiesons Poort Assemblages in southern Namaqualand, South Africa. PaleoAnthropology, 2016, 100-163.

Summerfield, M. A. (1982). Distribution, nature and genesis of silcrete in arid and semi-arid southern Africa. Catena, Supplement, 1, 37-65.

Tallavaara, M., Manninen, M. A., Hertell, E., \& Rankama, T. (2010). How flakes shatter: A critical evaluation of quartz fracture analysis. Journal of Archaeological Science, 37, 2442-2448.

Terradillos-Bernal, M., \& Rodríguez-Álvarez, X. P. (2017). The influence of raw material quality on the characteristics of the lithic tool edges from the Atapuerca sites (Burgos, Spain). Quaternary International, 433, 211-223.

Thackeray, A. I. (2000). Middle Stone Age artifacts from the 1993 and 1995 excavations of Die Kelders Cave 1, South Africa. Journal of Human Evolution, 38, 147-168.

Theron, J. N., Gresse, P. G., Siegfried, H. P., \& Rogers, J. (1992). The geology of the Cape Town area: Explanation of sheet 3318 (1:250,000). Republic of South Africa.

Thompson, E., Williams, H. M., \& Minichillo, T. (2010). Middle and Late Pleistocene Middle Stone Age lithic technology from Pinnacle Point 13B (Mossel Bay, Western Cape province, South Africa). Journal of Human Evolution, 59, 458-477.

Tomasso, A., \& Porraz, G. (2016). Hunter-gatherer mobility and embedded raw-material procurement strategies in the Mediterranean Upper Paleolithic. Evolutionary Anthropology, 25, 164-174.

Torrence, R. (1983). Time budgeting and hunter-gatherer technology. In G. Bailey (Ed.), Hunter-gatherer economy in prehistory (pp. 11-22). Cambridge University Press.

Tribolo, C., Mercier, N., Valladas, H., Lefrais, Y., Miller, C. E., Parkington, J., \& Porraz, G. (2016). Chronology of the Pleistocene deposits at Elands Bay Cave (South Africa) based on charcoals, burnt lithics, and sedimentary quartz and feldspar grains. South African Humanities, 29, 129-152.

Villa, P., Soressi, M., Henshilwood, C., \& Mourre, V. (2009). The Still Bay points of Blombos Cave (South Africa). Journal of Archaeological Science, 36, 441-460.

Volman, T. P. (1981). The Middle Stone Age in the southern Cape. Ph.D. dissertation. University of Chicago, Chicago.

Wadley, L. (2013). MIS 4 and MIS 3 occupations in Sibudu, KwaZulu-Natal, South Africa. South African Archaeological Bulletin, 68, 41-51.
Wadley, L., \& Jacobs, Z. (2006). Sibudu Cave: Background to the excavations, stratigraphy and dating. South African Humanities, 18, 1-26.

Wadley, L., \& Kempson, H. (2011). A review of rock studies for archaeologists, and an analysis of dolerite and hornfels from the Sibudu area, KwaZulu-Natal. South African Humanities, 23, 87-107.

Will, M. (2019). Sibudan. In S. Chirikure (Ed.), Oxford research encyclopedia of anthropology. Oxford University. https://doi.org/10.1093/acrefore/9780190854584. 013.35

Will, M., \& Mackay, A. (2017). What factors govern the procurement and use of silcrete during the Stone Age of South Africa? Journal of Archaeological Science: Reports, 15, 630-645.

Will, M., \& Conard, N. J. (2018). Assemblage variability and bifacial points in the lowermost Sibudan layers at Sibudu, South Africa. Archaeological and Anthropological Sciences, 10, 389-414.

Will, M., Parkington, J. E., Kandel, A. W., \& Conard, N. J. (2013). Coastal adaptations and the Middle Stone Age lithic assemblages from Hoedjiespunt 1 in the Western Cape, South Africa. Journal of Human Evolution, 64, 518-537.

Will, M., Bader, G. D. \&Conard, N. J. (2014). Characterizing the Late Pleistocene MSA lithic technology of Sibudu, KwaZulu-Natal, South Africa. PLoS One, 9, e98359.

Will, M., Kandel, A. W., \& Conard, N. J. (2015). Coastal adaptations and settlement systems on the Cape and Horn of Africa during the Middle Stone Age. In N. J. Conard \& A. Delagnes (Eds.), Settlement dynamics of the Middle Paleolithic and Middle Stone Age (Vol. IV, pp. 61-89). Kerns Verlag.

Wragg-Sykes, R., \& Will, M. (2017). Silcrete as a lithic raw material in global context: Geology, sourcing and prehistoric techno-economics. Journal of Archaeological Science: Reports, 15, 422-429.

Wurz, S. (2002). Variability in the Middle Stone Age lithic sequence, 115,000-60,000 years ago at Klasies River, South Africa. Journal of Archaeological Science, 29, 1001-1015.

Wurz, S. (1999). The Howiesons Poort backed artifacts from Klasies River: An argument for symbolic behaviour. South African Archaeological Bulletin, 54, 38-50.

Publisher's Note Springer Nature remains neutral with regard to jurisdictional claims in published maps and institutional affiliations. 